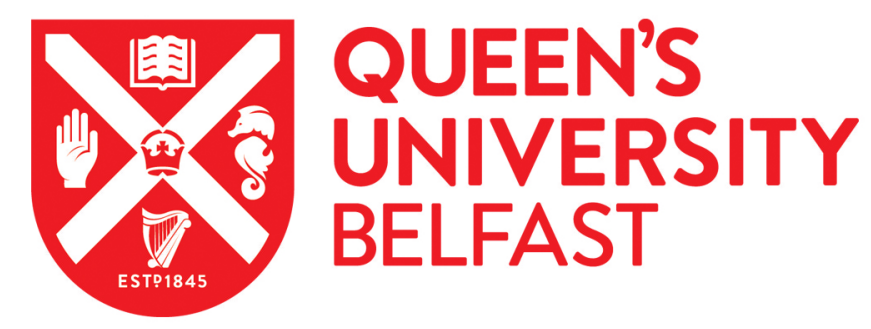

\title{
Managerial failure in mid-Victorian Britain?: Corporate expansion during a promotion boom
}

Campbell, G., \& Turner, J. D. (2015). Managerial failure in mid-Victorian Britain?: Corporate expansion during a promotion boom. Business History, 57(8), 1248-1276. https://doi.org/10.1080/00076791.2015.1026260

Published in:
Business History

Document Version:

Peer reviewed version

Queen's University Belfast - Research Portal:

Link to publication record in Queen's University Belfast Research Portal

Publisher rights

Copyright 2015 Taylor \& Francis

This is an Accepted Manuscript of an article published by Taylor \& Francis Group in Business History on 12/05/2015, available online: http://www.tandfonline.com/10.1080/00076791.2015.1026260.

\section{General rights}

Copyright for the publications made accessible via the Queen's University Belfast Research Portal is retained by the author(s) and / or other copyright owners and it is a condition of accessing these publications that users recognise and abide by the legal requirements associated with these rights.

Take down policy

The Research Portal is Queen's institutional repository that provides access to Queen's research output. Every effort has been made to ensure that content in the Research Portal does not infringe any person's rights, or applicable UK laws. If you discover content in the Research Portal that you believe breaches copyright or violates any law, please contact openaccess@qub.ac.uk. 


\title{
Managerial Failure in Mid-Victorian Britain?: Corporate Expansion during a Promotion Boom
}

\author{
Gareth Campbell and John D. Turner \\ Queen's University Management School \\ Queen's University Belfast \\ Belfast \\ BT7 1NN
}

\begin{abstract}
This paper examines the mid-1840s expansion of the British railway network, which was associated with a large deterioration in shareholder value. Using a counterfactual approach and new data on railway competition, we argue that the expansion of the railway companies, and their subsequent decline in financial performance, was not due to managerial failure. Rather, the promotion of new routes by established railways and mergers with other companies was part of a managerial strategy to maintain incumbent positions, and may have been preferable to not expanding whilst their competitors did.
\end{abstract}

\section{Published}

Campbell, G and Turner, J.D. (2015), 'Managerial Failure in Mid-Victorian Britain?:

Corporate Expansion during a Promotion Boom,' Business History, doi:

10.1080/00076791.2015.1026260

(http://www.tandfonline.com/doi/full/10.1080/00076791.2015.1026260)

Keywords: railways, managerial failure, expansion 


\section{Introduction}

As is well known, Chandler argues that managerial failure was at the heart of poor corporate performance in Britain from the late nineteenth century onwards. ${ }^{1}$ The managerial failure was that, unlike their American counterparts, British firms did not develop sophisticated impersonal administrative hierarchies. Much of the blame for this deficiency was placed by Chandler at the feet of family ownership, whereby executives were chosen for nepotistic reasons rather than managerial competence, resulting in amateurish managers. ${ }^{2}$ This widespread managerial malaise is alleged to have played a role in the decline of the UK economy. ${ }^{3}$ However, this view has been somewhat moderated by cliometric studies of late Victorian and early Edwardian companies. ${ }^{4}$

The Chandler thesis has recently been challenged by Hannah and ForemanPeck who show that ownership amongst the 337 largest UK companies in 1911 was highly dispersed and that large companies in 1911 had a separation of ownership from control, which meant that Chandler's caricature of the UK's corporate economy being dominated by large family-owned firms is far from reality. ${ }^{5}$ However, this divorce of ownership from control may have created an agency problem in that executives of these large companies mismanaged them and did not run them in the interests of shareholders. Notably, many of the largest companies in 1911 were railways, which were all characterised by a divorce of ownership from control. Despite this, Chandler has suggested that, unlike in the United States, Victorian and Edwardian railways were poorly managed. ${ }^{6}$ Notably, other studies hold up the railways as exemplars of managerial failure in this era, arising either from the lack of competition they faced or their diffuse ownership structure. ${ }^{7}$ 
In this paper, we ask whether managerial failure was present in the railway sector much earlier in the nineteenth century - at the point at which railway technology was widely adopted. ${ }^{8}$ The latter half of the 1840 s can be regarded as the heroic age of British railway construction, with the size of the network trebling within just a few years. However, this expansion resulted in an enduring legacy of low returns on capital, and meagre dividends, for railway shareholders. The focus of this paper is on whether the decision to expand, and subsequent investor losses, was due to managerial failure in that railway managers were hubristic, incompetent, or amateurish. Managerial failure may have occurred because many railway companies had diffuse ownership, and a divorce of ownership from control, due to their large capital requirements. $^{9}$

Alternatively, the losses for investors could simply be a by-product of the wide-scale adoption of the then-new railway technology. Each individual railway company had to decide whether to expand within the context of a changing competitive environment. The situation may be likened to a 'prisoner's dilemma'. The best outcome may have been for no company to expand, but given that new competitors were arriving and established rivals were expanding, it became optimal for each individual railway to also expand.

Our main contribution is that we examine the ways in which managers of incumbent railways responded to the threat from competitors and we ask whether or not the managers of these railways made strategic mistakes in their response to the promotion boom. Using a counterfactual approach, our results suggest that the expansion of the railway companies, and their subsequent decline in financial performance, was not necessarily due to managerial failure. Rather, the promotion of 
new routes by established railways and mergers with other companies was part of a strategy to maintain their incumbent positions.

We also make two other contributions to the literature on the 'Railway Mania'. ${ }^{10}$ As is well established in the historiography of British railway development, the rail network expanded substantially in the 1840s, with railways entering less populous areas and railways facing competition from rival companies. ${ }^{11}$ However, using details on every railway station and rail journey from Bradshaw's Railway Guide and the Djikstra shortest-path algorithm, we provide the first measure of the extent to which railway companies experienced an increase in competition in the 1840s. ${ }^{12}$ This enables us to ascertain whether the expansion of individual companies was correlated with an increase in competition. It is also well established in the historiography that the expansion of the railways during the 1840 s was followed by a diminution of profitability and poor returns for investors. ${ }^{13}$ Using share price and dividend data for every railway company, we provide an estimate of the extent to which shareholders were affected over the long run by the expansion of railways during the 'Railway Mania'. ${ }^{14}$

This paper also contributes to the growing historiography of British capital markets in the nineteenth century. To date, this literature has mainly focussed on the performance of the equity market, the structure of the London stock exchange, the role of dividends, and the characteristics of investors. ${ }^{15}$ Our paper contributes to this literature as the railway boom of the 1840s resulted in the largest expansion of the equity market during the entire nineteenth century, and, according to Grossman's figures, railways continued to dominate the market until the end of the century. ${ }^{16}$

The paper is structured as follows. The next section provides a brief historical sketch of the railway sector prior to and during the promotion boom. The third 
section examines the effect of the expansion of the network on competition. The fourth section describes the effect of network expansion on company performance and shareholder value. The fifth section considers whether the destruction of shareholder value in established railways was due to managerial failure. The sixth section considers whether firms which expanded the most experienced better financial performance. The seventh section is a brief conclusion.

\section{An overview of railways in the $1840 \mathrm{~s}$}

Although the early railways were private ventures, they required Parliamentary authorisation, mainly because of the need to force landowners to sell the land along the route that the railway was to take. As a result, railways were incorporated enterprises with shareholders enjoying limited liability. ${ }^{17}$ The first modern passenger railway was the Liverpool and Manchester railway, which was authorised in 1826, and opened in 1830. Subsequently, during the mid-1830s, many new railway companies were promoted, with Parliament authorising 59 new railways, having a nominal capital of $£ 36.4 \mathrm{~m} .{ }^{18}$ Figure 1 shows the railway network in existence in 1843, which was operated by just over 40 companies, with an average of 36 miles of track each.

\section{$<<$ INSERT FIGURE 1 >}

There was very strong economic growth and abundant harvests in 1843 and 1844 as a result of a period of good weather. ${ }^{19}$ Anticipating that these improved economic conditions might reinvigorate further investment in railways, William Gladstone, then President of the Board of Trade, moved for a Parliamentary Select Committee to consider the future regulation of railways. After considerable opposition, the Railways Act was passed in July 1844, requiring at least one train per 
day to carry passengers at a rate of $1 \mathrm{~d}$ per mile. ${ }^{20}$ The Act also left open the possibility of the government sanctioning new competing lines, and even nationalisation of lines authorised after 1844. Average fares for the ten largest railways fell, but the increase in passenger numbers and goods traffic was such that receipts grew by 42 per cent between 1842 and $1846 .{ }^{21}$ These increases in traffic and receipts were achieved with a relatively small increase of 25 per cent in the mileage open of the ten largest lines. These changes led to most of the large established railway companies increasing their dividends substantially. ${ }^{22}$

During 1844, projected railways had been scrutinised by a Railway Board, which took an overall view of railway proposals and wanted Parliament to ration schemes with a view to building an integrated national rail network. ${ }^{23}$ However, Parliament ignored 35.5 per cent of their recommendations, ${ }^{24}$ and the Railway Board was disbanded on July $101845 .^{25}$ This made it more likely that a railway bill would be evaluated on its social costs and benefits in isolation from national considerations, a process which was sub-optimal as it did not take account of network externalities and wasteful competition arising from duplication of routes. ${ }^{26}$

The promotion of new railway lines reached unprecedented levels in the autumn of 1845 . An estimated 1,263 new railways were attempting to meet the November 30 deadline for the submission of proposals for the next Parliamentary session. ${ }^{27}$ Such was the level of promotion that Herapath's Railway and Commercial Journal and the Railway Times, the two leading railway periodicals, both printed up to three weekly supplements during September and October 1845 to cope with the demand for advertising new railway schemes. ${ }^{28}$ As can be seen from Figure 2, there was a very dramatic increase in adverts in the Railway Times in the late summer and 
autumn of 1845 , and this coincided with the turning point of the railway share price index ${ }^{29}$.

\section{$<$ INSERT FIGURE 2 >}

The increase in promotional activity which followed the disbandment of the Railway Board, and the likelihood that Parliament would be lenient in its authorisation process, began to raise concerns. The Times, in a series of articles from July onwards, raised the alarm about the effects of the new proposed railways. ${ }^{30}$ The Economist commenced publication of its 'Railway Monitor' on October 4 1845, in which they began an extensive and detailed critique of the negative effects which these new railways would have. ${ }^{31}$

As can be seen from Figure 2, after the initial declines at the end of 1845, railway share prices fell steadily during the remainder of the decade, having fallen by 66 per cent from their peak by April 1850. During this time, those lines which had been promoted during the boom, and which had received Parliamentary authorisation, began laying their lines, with estimates by Mitchell suggesting that railway construction represented 5.7 per cent of GDP in 1846, 6.7 per cent in 1847, and 4.7 per cent in $1848 .^{32}$

To place the expansion of the railway industry during the 1840s in its long-run context, Figure 3 shows the total par value (i.e., actual capital invested) of British railways between 1825 and 1870, which are quoted on the London Stock Exchange and reported in the Course of the Exchange. Figure 3 clearly suggests that the expansion of railways was substantial and dramatic during the mid-1840s.

$<$ INSERT FIGURE 3 >> 


\section{Network Expansion}

The magnitude of the railway network's extension between 1843 and 1850 can be seen from Figure 1, which illustrates the railways which had been constructed up to 1843 in yellow, and those constructed between 1843 and 1850 in blue. The early lines provided the spine of the network, which was then considerably expanded as a result of projects which were promoted during the promotion boom. In this section, we consider two aspects of the network expansion. First, we look at the differences in districts served by railways in 1843 and 1850 to see to what extent the expansion of railways was into less populous, and therefore less remunerative, areas. Second, we look at the extent to which there was duplication of routes and an increase in competition as a result of the expansion of the network.

\subsection{Districts served by Railways}

The population of an area would have an impact on both the potential for passenger traffic, which represented 51.1 per cent of receipts in 1850 , and to some extent the volume of freight. ${ }^{33}$ Thus a possible problem with the railway construction of the 1840s was that the most populous districts were already being served by the railway network, with the result that any subsequent construction would either involve increasing the density of the network within existing areas or expansion into less populous districts. To examine this issue, the population, as reported in the 1851 Census, of the registration districts (of which there were 694 in Great Britain) served by railways in 1843 have been compared to those served by railways in 1850 , after most of the railways which had been projected during the boom had been constructed. $^{34}$ 
The names of each railway station open in 1843 and 1850 were obtained from Bradshaw's Monthly General Railway and Steam Navigation Guide. The corresponding registration district for each of these stations was determined by using the accompaniment to the 1851 Census, the Index to the Names of the Parishes, Townships, and Places in the Population tables of Great Britain, and supplemented with the GENUKI Gazetteer and the Vision of Britain historical units database. The population of each district in 1843 and 1850 was estimated by assuming that the population changed in a linear fashion between the 1841 and 1851 Census.

To analyse the differences in the characteristics of districts served by railways in 1843 and 1850, the figures for the median district are reported, and the differences in medians between 1843 and 1850 are shown. ${ }^{35}$ Table 1 shows that those districts which had been newly served by a railway station between 1843 and 1850 had substantially lower populations and population densities than the districts which had been served prior to the Mania. This suggests that much of the construction which occurred between 1843 and 1850 was into areas where there would potentially be less traffic. The Mann-Whitney tests in Table 1 confirm significant differences between the districts served in 1843 , and the new districts in 1850 , in terms of population, population density, mileage and the number of stations. ${ }^{36}$

\section{$<$ INSERT TABLE $1>>$}

Table 1 also shows that there was an increase in the extent of the network within districts which had already been served prior to 1843 , with an increase in both the railway mileage and the number of stations in these areas. This implies that there was also a considerable increase in the density of the network within existing districts, which may imply that there was duplication of some routes. 


\subsection{Competition and duplication of routes}

To examine the extent to which construction of new railway lines duplicated existing routes, we compare levels of competition in the railway network in 1843 with 1850 . To compare levels of competition, we ask whether passengers could have taken an alternative route to make their journey. If no alternative railway route was available for a particular railway line, then we regard that line as having a monopoly. If an alternative was available, the degree of competition was measured by calculating the additional cost to passengers from taking the alternative rather than the original line. There are two basic assumptions underlying this measure of railway competition.

First, it assumes that railway companies competed on price to attract passengers to switch to a slower / longer route. There is ample evidence to suggest that companies competed aggressively (and ruinously on occasions) on fares and rates in order to attract passengers and freight from shorter / faster rivals. ${ }^{37}$ Even the Great Western Railway was not immune from attempting to compete with a superior rival by cutting its rates. ${ }^{38}$ Second, it assumes that service demand is relatively elastic. In other words, passengers and other users are relatively sensitive to changes in combined travel costs (i.e., time as well as fares and freight rates). Notably, in terms of fares and freight rates, the price elasticity of demand is assumed to be unitary in the social savings literature. ${ }^{39}$ It is possible that other factors such as the safety of each line, its reliability, or the quality of its service, may also have influenced passengers, but they were likely to have been secondary considerations. The fact that companies competed aggressively for custom even though they had an inferior route would also tend to suggest that the service demand was relatively elastic.

To perform the analysis, the railway routes which were listed in Bradshaw's Railway Guides in 1843 and 1850 were digitised. This guide included information on 
which stations were directly connected by a segment of railway line, and how long that segment was. By considering all of the segments in Great Britain, it was possible to calculate the shortest route between every pair of stations on the railway network. Assuming that a passenger could begin at any of the railway stations in the network and attempt to travel to any of the other stations, $n(n-1)$ journeys are possible, where $n$ is number of stations. In 1843, there were 353 stations, meaning that 124,256 journeys were possible, and in 1850 , there were 1,480 stations, implying $2,188,920$ possible journeys.

For 1843 and 1850, the shortest path between each station was calculated by applying the Djikstra shortest-path algorithm. ${ }^{40}$ The Djikstra shortest path algorithm as applied to the railway network calculates the shortest path between railway stations by first evaluating the distance between a starting railway station, and all neighbouring railway stations. Once this calculation had been performed this railway station was marked as visited. The process was repeated by evaluating the distance between another railway station and all of its unvisited neighbouring railway stations. The minimum cost of travelling between railway stations was recorded, and only overwritten if a route with a lower cost was discovered. After iterating through all railway stations, the optimal route between all railway stations was determined.

Travel between two stations was only possible when a railway line connected them. The cost of travelling between adjacent stations was defined as the mileage of railway track between them. In 81 per cent of segments, the mileage is stated in Bradshaw's Railway Guide. In 16 per cent of segments, the travel time was used, and converted to a distance assuming a speed of $20 \mathrm{mph}$. For the remaining three per cent of stations, we only had the departure time of trains so the straight line distance is used. Although stations within London were not directly connected in either 1843 or 
1850 , they are regarded as a single terminus, as otherwise travel between much of the network would not be possible.

Robustness tests shown in Appendix Table 1 consider whether the main results change when using alternative scenarios for those 16 per cent of segments where travel time is used to estimate the distance between stations. Leunig has found that in 1850 the average, as the crow-flies, speeds on major routes was $22.7 \mathrm{mph}$ and on minor routes was $17.8 \mathrm{mph}$, with a rule of thumb being that track speeds exceeded crow-flies speeds by 15 per cent. ${ }^{41}$ The baseline results assumed a speed of $20 \mathrm{mph}$, but Appendix Table 1 shows that using a reasonable range of other possible speeds, namely $15 \mathrm{mph}$ or $25 \mathrm{mph}$, has little impact on the findings.

These Djikstra shortest-path calculations enabled the development of a matrix which reported the length of the shortest route, where possible, between each of the stations in the rail network. A subset of this matrix, for a selection of stations in 1843, is given in Panel A of Table 2, which shows the distance in miles between several major stations.

\section{$<<$ INSERT TABLE $2>>$}

To analyse the availability of alternative routes, the Djikstra shortest-path analysis was then repeated, but we assumed that an individual rail line between two stations had been removed from the network. This reveals how easy it was for passengers to substitute away from this line, and therefore the degree of competition to which it was exposed.

As an example, Panel B of Table 2 shows the shortest route between a selection of major stations in 1843, assuming that the line between Blisworth and Roade, part of the London and Birmingham railway, was not available. Its removal implies that 40 of the 72 possible journeys can no longer be undertaken by rail. This 
implies that this segment of railway line had a monopoly on traffic between these 40 pairs of stations.

This analysis was repeated for each segment in the network. Table 3 shows how many segments had a monopoly on the routes which they affected, meaning that no substitute was available. In 1843, 67 per cent of the segments had no substitute available. An analysis of these 1843 lines in 1850, suggests that only 18 per cent had no substitute available after the expansion of the network. When the full network in 1850 is analysed, a similar pattern emerges, with only 29 per cent of lines having no substitutes.

To determine which lines were of most importance, the segments were categorised into quintiles, depending on the number of journeys which they affected. Table 3 suggests that the least important lines (e.g., minor branch lines) were least exposed to competition, but the decline in the number of segments which had a monopoly between 1843 and 1850 occurred across segments irrespective of their importance.

\section{$<$ INSERT TABLE 3 >>}

The results in Table 3 suggest that the number of lines which enjoyed an absolute monopoly was reduced between 1843 and 1850. However, it could be possible that the substitutes which were available in 1850 required such a circuitous journey that they were an implausible alternative for passengers. To estimate the additional cost to passengers from using a competing line, the median increase in journey distance which would have been required by taking the best substitute was estimated. An example of this is shown in Panel C of Table 2 with the removal of the line between Sawley and Long Eaton Junction, which was part of the Midland Counties line. For this segment, alternative routes could be taken which enabled all of 
the journeys to be made, but at an additional cost. The median increase in distance due to the unavailability of this line was 20 miles, or 8.5 per cent of journey distance, suggesting that this segment was exposed to competition as passengers could have taken other routes to their destination for a relatively modest increase in journey time.

The median across all segments is reported in Table 4. Overall, the median increase in journey times by taking the best substitute was 22 per cent for lines in 1843, 9 per cent for those same lines in 1850, and 6 per cent for all lines in 1850 . Mann-Whitney tests suggest that there were significant differences in the cost of taking a substitute between 1843 and 1850, when all segments are analysed. When broken down by importance of segment, eight of the ten Mann-Whitney tests indicate significant differences between 1843 and 1850.

\section{$<$ INSERT TABLE 4 >>}

The analysis was also repeated to see whether the increase in competition had more of an effect on short or long journeys. For each segment where an alternative was available, the median increase in journey distances for each of these categories was calculated. From Table 4, we can see that if passengers had been undertaking short journeys (less than 10 miles) and had been forced to take the best available substitute, they would have needed to increase their journey time by 1,765 per cent in 1843 , by 1,026 per cent for those same lines in 1850 , and by 959 per cent for all lines in 1850. Passengers undertaking the longest journeys would have faced an increase by taking an alternative of 5 per cent in 1843, by 3 per cent for those same lines in 1850 , and by 3 per cent for all lines in 1850 . There was also a substantial and significant decrease in the cost of substitution between 1843 and 1850 for journeys of intermediate length. 
The results across each category of journey length suggest that the additional cost for rail passengers of taking an alternative approximately halved between 1843 and 1850. In 1850, railway lines retained an effective monopoly over short journeys, as the cost of substitution remained very high, but for journeys over 50 miles, the additional cost had fallen to 30 per cent, and for journeys over 100 miles to just 11 per cent.

\section{Decline in Financial Performance during 1840s}

The promotional frenzy resulted in railways being exposed to greater competition for traffic and companies expanding simply in order to kill off a rival company. Notably, The Economist in 1848 stated that the pre-Mania system differed from the post-Mania one in that unremunerative lines extended to thinly populated districts and the established lines had to share their traffic with newly-established routes. ${ }^{42}$ Table 5 shows how mileage, receipts and passenger numbers changed during the 1840s. Railway mileage grew by 205 per cent. However, although the number of passengers grew by 180 per cent, passenger receipts only grew by 109 per cent, which partially reflects the effect of competition.

\section{$<<$ INSERT TABLE $5>>$}

To evaluate the effect on companies, Table 6 compares averages for a number of variables for established companies (i.e., those established before 1843) in 1843 and 1850 and new railways (i.e., those established from 1844 onwards) in 1850 . The results illustrate that the mileage operated by established companies grew dramatically between 1843 and 1850, from an average of 36 miles to 153 miles, reflecting both expansion and consolidation due to amalgamations, whilst the 
population/mile ratio for established companies fell from an average of 11,761 in 1843 to 7,013 in 1850.

The competition faced by the railways is then analysed. A particular route could be exposed to competition from lines run either by the same company, or by another company. In 1843,72 per cent of the routes had a complete monopoly, with no other route providing any competition. However, by 1850 , only 32 per cent of the routes run by established companies had a complete monopoly. When analysed only with respect to competition from other companies, 85 per cent of routes had a monopoly in 1843 , but this had fallen to 66 per cent by 1850 for the established companies. It seems likely that this increase in competition played a role in the reduction in average fares, which fell for every class of passenger.

These results illustrate three forces impacting on the financial performance of the railways. Firstly, the expansion of the railways led to reductions in the population/mile which were served. Secondly, many railway companies promoted lines which at least partially duplicated their own existing lines. Thirdly, there was an increase in competition between companies.

These fed into a fall in average receipts per mile between 1843 and 1850, with the result that profit per mile falls from $£ 1,811$ in 1843 to $£ 1,231$ in 1850 . The average return on capital also falls in this period and the dividend/par ratio nearly halves. The new railways which are operating in 1850 have even lower profits per mile and a return on capital below that of the established companies.

\section{$<<$ INSERT TABLE 6>>}

Much of the blame for the reductions in financial performance at the time was blamed on the overexpansion which had taken place. For example, The Economist stated in 1848 that all recent experience had shown that the lines which had recently 
been constructed had shown little or no profit. ${ }^{43}$ This was partly because they often competed with other lines, and as Gale, a contemporary jurist, argued: 'the obvious effect of the concession of a competing line is to diminish, if not destroy, the profits of the old line; and it is not likely that it can, by entering into competition with the old line, itself be highly profitable'. ${ }^{44}$ Arnold and McCartney estimate that in 1850 , the return on equity of the York and North Midland's pre-Mania network was 10.1 per cent, whereas the return on the Mania part of its network -0.3 per cent. ${ }^{45}$

To ascertain the effect of the promotion boom of the 1840s on dividends over the long run, the dividend rate of each railway company over the period 1832-70 was obtained from the Course of the Exchange, and aggregated to calculate the total dividend payments of the railway industry. As shown in Figure 4, between 1843 and 1847, dividends as a percentage of par value had increased from 4.7 per cent to 7.0 per cent. However, in the aftermath of the expansion of the network, dividends then fell dramatically, reaching just 2.7 per cent by the end of $1850^{46}$. Dividends recovered slowly during the 1850 s and even after a temporary boom in the 1860 s, dividends never got near their pre-boom heights again.

\section{$<<$ INSERT FIGURE 4 >>}

Although dividends did not begin to decline until 1847, when many of the new lines were being opened, share prices began to fall in the autumn of 1845 as investors began to foresee the reduction in payouts which they could expect. ${ }^{47}$ Figure 5 illustrates the substantial increase in the number of railway securities which were listed on the London Stock Exchange during the period, and of particular note is the huge rise in the number of securities listed in late summer and autumn of $1845^{48}$. Even this underestimates the level of railway promotion taking place in the autumn of 1845 , as not all of the projected lines obtained a stock market listing. 


\section{$<<$ INSERT FIGURE 5 >>}

The extent of this promotion was not clear prior to the latter half of 1845 , but when the unprecedented degree of new railway formation became obvious, investors began to revise their expectations and started to foresee the expansion in the network which would eventually occur. As fears of diminishing returns and more competition increased, share prices started to fall and the market crash occurred in October 1845. As the decade progressed and the network continued to expand, the effects of the new lines became increasingly clear and shareholder fears deepened, depressing share prices further. At each annual meeting their fears were confirmed and dividends were repeatedly cut as the railway companies were forced to deal with the new reality of lower returns on capital. The dramatic decline in share prices during the latter half of the 1840s suggests that shareholder value was substantially reduced at this time.

\section{Managerial Strategy}

Given that the expansion of the established railways was followed by declining share prices, it could be argued that the directors of these companies did not effectively maximise shareholder wealth. This could have been due to agency problems leading to empire building or hubris which resulted in overly optimistic expectations about the potential for expansion or incompetence/inexperience. However, there is evidence that the established railway companies were particularly fearful of the threat posed by increases in competition.

The line between London and Southampton can be used to illustrate the situation which established railways faced. In 1843 the London and South Western (L\&SW) had a monopoly on the entire route, with it being impossible to use any other railway for any part of the journey. However, by 1850 the L\&SW traffic was 
threatened from the north by the Great Western Railway (GWR), and from the east by the South-Eastern (SE), and London, Brighton and South Coast (LBS). These companies had promoted and constructed additional lines which connected their main routes to that of the L\&SW. It became possible for passengers to complete much of the journey on these other railways, and complete only the final section via the L\&SW.

For example, the direct route offered by the L\&SW between London and Southampton was 80 miles. Alternatively, in 1850, passengers could have travelled via the GWR line for 56.25 miles between London and Basingstoke, only completing the final 32 miles by the L\&SW, giving a total distance of 88.25 miles.

Similarly, passengers could have travelled 28 miles via the LBS from London to Reigate Junction, then 30.33 miles via the South-Eastern to Farnborough, and then the final 54 miles via the L\&SW, giving an overall mileage of 112.33. Finally, passengers could have avoided the L\&SW entirely by travelling on the LBS line, but the overall mileage would have been 133.25 miles.

Although the journeys would have been slightly longer, they could have easily been made attractive by the GWR, SE and LBS offering low fares on the newly built extensions. However, it would be difficult to argue that there was managerial failure on the part of the GWR, SE and LBS who constructed the lines. The short extensions offered the opportunity to increase traffic on their main lines by diverting it from the L\&SW.

A counterfactual analysis can be used to assess whether the strategy pursued by the managers of the established railways during this period was optimal. Three scenarios are considered. First, the railway companies of 1843 remained unchanged i.e., managers had done nothing - no expansion and no mergers and the competing 
companies built the other lines instead. Second, the railway companies of 1843 had pursued the mergers which they actually did pursue, but did not undertake any additional expansion. Third, the actual situation in 1850 whereby the railway companies of 1843 had engaged in mergers and undertook substantial additional expansion.

The general results of the counterfactual analysis in Table 7 reveal the following. The worst scenario in terms of competitive pressures is when managers do nothing. In other words, had managers simply done nothing, there would have been more competition from rivals than there actually was.

Engaging in mergers, but not expanding, produces a marginally better result in terms of competitive pressures than simply doing nothing. Notably, the inevitability of amalgamation was pointed out in 1844 by the Railway Times, when they said 'two companies could not fight and ruin themselves at low fares for the benefit of the public, but would of course coalesce at their expense. ${ }^{, 49}$

It was common for large companies to merge with each other. For example, the London and North Western was formed by a merger of the already major companies of the London and Birmingham, the Manchester and Birmingham, the Grand Junction, the Liverpool and Manchester and several smaller lines. At the end of 1850, the London and North-Western had a paid-up capital greater than that of the Bank of England.

Another form of amalgamation involved a large parent company paying a guaranteed rate of dividend to the shareholders of another smaller company for the long-term use of their line. The difficulty with this approach was that 'the whole risk of a diminution of receipts is thrown upon the purchaser'. ${ }^{50}$ These guarantees represented a 'certain future preferable claim on the receipts of the main line' ${ }^{51}$ If the 
purchased line earned more than the fixed dividend, the parent company kept this as profit, but if it earned less, as many did during the downturn, the parent company would have to subsidise it from its other lines.

Another possibility may have been collusion. However, with the rapid rise of new competitors, it would have been risky to have relied on collusion instead of expansion. Once the competitors had themselves expanded and opened their lines, they may have found that there was an incentive to compete. Experience had shown that there had been damaging price wars in the past, such as between the Midland Counties and the Birmingham and Derby. ${ }^{52}$ The solution to these had been full amalgamations, rather than collusion.

The best scenario in Table 7 in terms of competitive pressures is what actually happened i.e., companies engaged in mergers and expanded. Notably, the monopoly over routes of some of the major railways was considerably enhanced by their expansion and not their mergers. In other words, had managers not expanded their rail networks during the boom, their companies would have faced even greater competitive pressures than they did.

\section{$<<$ INSERT TABLE 7>>}

This counterfactual analysis suggests that one of the most effective means of addressing the threat from parvenus was for the established railways to promote their own lines. Ultimately, the actions of companies were likely motivated by a fear that if they did not project a new line themselves, the route would be built by someone else, which would increase their exposure to competition. The Economist, for example, suggested that few had been undertaken for their own merits, but for the purpose of averting threatened opposition. ${ }^{53}$ Jackman has noted that 'nothing was more common than to see a company eagerly seeking authority to make a branch which could only 
bring it a loss, but which, it was feared, would cause still greater loss if it fell into the hands of a rival'. 54

To analyse the relationship between expansion and the threat of competition, we run a series of regressions which are shown in Table 8 . The dependent variable in each regression is the difference between the actual mileage of railway open for each company in 1850 , minus the counterfactual of the number of miles which would have been open if the companies had merged but not expanded.

\section{$<$ INSERT TABLE $8>>$}

Table 8 reveals that those companies which were likely to have greater monopoly power under the counterfactual, expanded the least. This implies that those firms which had the greatest potential exposure to competition were those which expanded the most. Even though the sample size is necessarily small, the results indicate a highly significant relationship.

Table 8 also considers the impact of other control variables on expansion. Companies which already had the largest networks under the counterfactual were those which were more likely to expand, implying that large companies wanted to get even larger. However, we find little evidence of a relationship between expansion and the population served by the railways per mile. After controlling for these other variables, the relationship between potential competition and expansion remains significant. This suggests that the threat of competition was an important consideration in the decision by railways to expand during this period.

\section{Size and Performance}

Although the desire to head off competition may have provided a rationale for expansion, it is possible that this strategy may have been misguided. The pertinent 
question is whether expansion was valuable, given the new environment within which firms were operating. They were faced with numerous potential competitors, with a torrent of applications for new railway schemes, particularly in 1845. Although companies engaged in lobbying against rivals and attempted to get them thrown out of Parliamentary contests, railway managers were fighting a losing battle on this front. Parliament sanctioned a large proportion of the new schemes.

Given the expansion of others, firms had to choose the best strategy to deal with this situation. To analyse whether expansion was optimal, we consider the crosssection of firms in 1850, and analyse whether firms with larger networks performed better. We begin in Table 9 by analysing the relationship between the mileage operated by each company, and the Return on Capital Employed of that firm. ${ }^{55}$ Each variable is expressed in $\operatorname{logs}$ to allow an estimate of the percentage impact on profitability from a one percentage increase in mileage of track open. The results indicate a highly significant positive relationship, with larger firms enjoying higher returns on capital.

\section{$<$ INSERT TABLE 9 >}

A caveat to this result is the small sample size, which arises because profitability data was available for the full year of 1850 for just 17 companies $^{56}$. To confirm the robustness of our results, we use several other components of financial performance, for which larger sample sizes are available. Several Parliamentary Papers $^{57}$ reported detailed information on the revenue for each railway company, broken down into how much was received from carrying goods, and how much from passengers. Another Parliamentary Paper also reported the capital employed by each firm. $^{58}$ 
From this data, we calculate revenue to capital measures, and analyse whether larger companies earned higher revenues for each unit of capital employed. The results suggest a significant positive relationship between the size of a company's network and total receipts, receipts from goods, and receipts from passengers.

To analyse the source of this advantage to large firms, we exploit the detailed information provided on revenues from passengers, which is broken down for each company into the number of passengers who travelled, and the average fare per mile. From this information, we can also calculate the total passenger miles, and the average number of miles travelled by each passenger.

To decompose the determinants of revenues, we split the receipts to capital variable into several ratios, as shown in Equation 1.

$$
\frac{R}{C}=\frac{R}{Z} * \frac{Z}{P} * \frac{P}{D} * \frac{D}{M} * \frac{M}{C}
$$

$$
\begin{array}{ll}
\text { Where: } & \mathrm{R}=\text { Receipts from Passengers } \\
\mathrm{Z}=\text { Total Passenger Miles } \\
\mathrm{P}=\text { Number of Passengers } \\
\mathrm{D}=\text { Population of Districts served by that railway } \\
\mathrm{M}=\text { Miles of track open } \\
\mathrm{C}=\text { Capital Employed }
\end{array}
$$

By taking logs of both sides, and referring to the logged variables in lower case, this can be rewritten as Equation 2.

$$
\frac{r}{c}=\frac{r}{z}+\frac{z}{p}+\frac{p}{d}+\frac{d}{m}+\frac{m}{c}
$$

This implies that the passenger receipts to capital ratio of each railway will be affected by an improvement or deterioration in any of these component ratios i.e., an increase in receipts per passenger mile $(\mathrm{r} / \mathrm{z})$, or the number of miles travelled by each passenger (z/p), etc. would tend to improve the receipts to capital ratio. 
We then regress the size of each company's network against each ratio individually. The results are shown in Table 10. As all variables are in logs, the coefficients can be interpreted as the percentage change in a ratio, from a one percent increase in the size of a company's mileage of track open. This methodology allows us to analyse the mechanisms by which size affects financial performance. Given the relationship in Equation 2, the betas showing how size affects each component ratio can be summed to obtain the overall impact that size has on the receipts to capital ratio.

\section{$<$ INSERT TABLE $10>>$}

Size has a small positive impact on receipts per passenger mile (r/z), implying that larger firms earned slightly higher fares for each mile that a passenger travelled. There is a stronger relationship between size and the average number of miles travelled by each passenger (z/p). This means that any given passenger tended to travel further on a large railway than on a small one, therefore paying more to the railway company for their ticket.

Size also has a large positive effect on the ratio between the number of passengers who travelled on the railways, and the number of people who lived in districts served by that railway ( $\mathrm{p} / \mathrm{d})$. This could be because people had a greater propensity to travel on trains operated by large companies, or it could reflect greater through traffic, with passengers using the lines even though they did not live in surrounding areas.

These three factors produced positive benefits for large companies. However, these advantages were somewhat mitigated by other factors. Larger companies tended to serve lower populations per mile of track open $(\mathrm{d} / \mathrm{m})$. This reflects their expansion into less populous areas, and the duplication of their own lines. They also tended to 
invest more capital for each mile of track open, or in the setup of the ratio, obtain less track for every unit of capital invested $(\mathrm{m} / \mathrm{c})$ which could reflect better quality, or poorer cost control.

Despite these mitigating factors, the overall impact of size was positive ${ }^{59}$. Firms with larger networks experienced better financial performance, as measured by the passenger receipts to capital ratio. By expanding, and reducing competitive threats, the railways could increase fares, keep passengers on their lines for longer, and gain more through traffic.

This suggests that the expansion strategy that was pursued by many firms was not an example of managerial failure. Expansion may have reduced profits over time between 1843 and 1850, but the market as a whole changed during this period, and firms had to respond to the new environment. A strategy of not expanding whilst everybody else was would not have been optimal. In the cross-section, it was the larger firms that enjoyed the better performance.

\section{Conclusions}

The chief finding of this paper is that there is little evidence of managerial failure in mid-Victorian railways. There was a large expansion in the railway network, and this was associated with declining financial performance. However, we argue that managers responded in the best way they could, given the authorisation of duplicate and uneconomic railway schemes at this time. An alternative strategy of not expanding whilst competitors did, would not have been advantageous, as it was the largest firms who performed best.

Thus, the well-documented managerial malaise in British railways which existed in the late Victorian era had not set in during the 1840s. 
A large body of evidence suggests that later Victorian railways were poorly managed. ${ }^{60}$ So what changed? One possibility is that ownership had separated from control by the later part of the Victorian era. However, we can discount this, as ownership was always separated from control in the railways. ${ }^{61}$

Another, more likely, possibility is that the railway industry moved from being competitive in the period under consideration to being monopolistic. ${ }^{62}$ In addition, there may have been a shift in focus, so that the later railways were run not so much for their shareholders, but for the benefit of other stakeholders, including their managers, industrialists, passengers, and the State. ${ }^{63}$ 


\section{Notes}

${ }^{1}$ Chandler, Scale and Scope, pp.239-94. See Cheffins, "History" for an excellent survey of the Chandler thesis.

${ }^{2}$ Wilson, British Business History, p.154.

${ }^{3}$ Chandler, Scale and Scope, pp.240-2; Elbaum and Lazonick, pp.572-3.

4 McCloskey, "Did Victorian Britain Fail?"; McCloskey and Sandberg, "From Damnation to Redemption".

5 Foreman-Peck and Hannah, "Extreme Divorce"; See also Hannah, "Divorce of Ownership from Control".

${ }^{6}$ Chandler, Scale and Scope, 252-4.

7 Arnold and McCartney, "Rates of Return"; Cain, "Railways", p. 120; Crafts et al. "Were British Railway Companies'; Crafts et al. "Total Factor Productivity Growth'; Mitchell et al., 'How Good Was the Profitability'; Irving, "Profitability and Performance", p. 58.

${ }^{8}$ The period can be thought of as being the wide-scale adoption phase of a new technology, as proposed by Pástor and Veronesi, "Technological Revolutions".

${ }^{9}$ Cheffins, Corporate Ownership, pp.157-9.

${ }^{10}$ Ever since contemporaries coined the term 'railway mania' to describe this episode, its occurrence has been subsequently explained by mania, delusion and irrational behaviour on the part of investors. Writing in 1851, Francis, History of English Railway, vol. 1, p.vii-viii describes the development of the railways in the mid-1840s as "a delusion as popular as any chronicled in Dr. Mackay's interesting work". Subsequently, the following have viewed the Railway Mania as being attributable to irrational behaviour on the part of investors: Hyndman, Commercial Crises, p.55; Lewin, Railway Mania; Gayer et al., Growth and Fluctuation, vol. I, p.380; Simmons, The Railway, chap. 2; Kindleberger, Financial History, p.201; McCartney and Arnold, "The Railway Mania"; Eatwell, "Useful Bubbles".

${ }^{11}$ Mitchell, "The Coming"; Kenwood, "Railway"; Simmons, The Railway; Gourvish, "Railways".

${ }^{12}$ See Kirk, Advanced Djikstra for details of this algorithm.

${ }^{13}$ See Lewin, Railway Mania, Mitchell, "The Coming”; Jackman, Development of Transportation; Kenwood, "Railway"; Reed, "Railways"; Simmons, The Railway; Gourvish, "Railways"; Kostal, Law. See also Nairn, Engines; Odlyzko, Collective Hallucinations; Miller, Railway.Com; Bryer, “Accounting”; Campbell, 'Myopic rationality'; Nairn, Engines; Odlyzko, Collective Hallucinations; Miller, Railway.Com; McCartney and Arnold, "The Railway Mania", "Capital Clamours".

${ }^{14}$ For long-run estimates of railway industry profitability, see Arnold and McCartney, "Rates of Return".

15 Acheson et al. "Rule Britannia"; Braggion and Moore, "Dividend Policies"; Grossman, "New Indices"; Michie, London Stock Exchange; Rutterford et al., "Nation of Shareholders".

${ }^{16}$ Grossman, "New Indices," p.130.

${ }^{17}$ Jackman, Development of Transportation, p.522.

${ }^{18}$ The Economist, October 4, 1845, p.949

${ }^{19}$ Barnes, History of Corn Laws, p.253.

${ }^{20} 7$ \& 8 Vict. c. 85 .

${ }^{21}$ Parliamentary Papers, 1847, LXIII, p.179, Railways. Summary of returns, showing the number of passengers carried on 63 railways of the United Kingdom during the year ending 30 June 1846, the fares of each class, and the receipts from each class of passengers, and for goods.

${ }^{22}$ The only notable exceptions were the four companies already paying a dividend of 10 per cent.

${ }^{23}$ Lewin, Railway Mania, p.18; Casson, The World's First Railway System, p. 277.

${ }^{24}$ Lewin, Railway Mania, p.17.

${ }^{25}$ Railway Times, July 19, 1845, p.1208.

${ }^{26}$ See Casson, The World's First Railway System, p. 277.

27 The Times, November 17, 1845, p.4 This figure underestimates the extent of promotion as 335 companies not on this list went on to petition Parliament (The Times, January 14, 1846, p.6).

${ }^{28}$ See Railway Times October 4, 1845, p.1768.

${ }^{29}$ Campbell et al, 'Role of the Media'

${ }^{30}$ The Times, July 1, 1845, p.4; July 30, 1845, p.4 As the deadline for new promotions drew near The Times asked "if six millions a year has been difficult," which was their estimate of the annual cost of constructing the early railways, "and twenty-two millions a year is almost a four times greater difficulty", the estimated annual cost of railways which had been authorised but not constructed, "what can we say to the enormous - the stupendous - the infinite sums that would be required for the projected schemes" (The Times, November 17, 1845, p.4). 


\begin{abstract}
${ }^{31}$ The Economist, October 4, 1845, p.950-953
${ }^{32}$ Mitchell "The Coming of the Railway"

${ }^{33}$ Parliamentary Papers, Railways. Return, showing the number of passengers conveyed on all the railways in England and Wales, Scotland, and Ireland, respectively, during the half-year ending the 30th June 1850, 1851 and Parliamentary Papers, Railways. Return, showing the number of passengers conveyed on all the railways in England and Wales, Scotland, and Ireland, respectively, during the half-year ended the 31st December 1850, 1851.
\end{abstract}

${ }^{34}$ Calculated from data in 1851 Census, obtained from Parliamentary Papers, Census of Great Britain. 1851. Tables of the population and houses in the divisions, registration counties, and districts of England and Wales; in the counties, cities, and burghs of Scotland; and in the islands in the British seas, 1851.

${ }^{35}$ The median is a conservative measure as some districts, especially those in London, had extremely high populations. As most of these highly populated districts were already served by the railways in 1843, this would have increased the differences with 1850

${ }^{36}$ Mann and Whitney, "Test of Two Random Variables"

${ }^{37}$ Lewin, Railway Mania, pp.343, 402, 411-6, 437, 445-6, 462.

${ }^{38}$ Hawke, "Pricing Policy," p.81.

${ }^{39}$ Leunig, "Time is Money," p.656.

${ }^{40}$ See Kirk, Advanced Djikstra.

${ }^{41}$ Leunig, "Time is Money"

${ }^{42}$ The Economist, November 18, 1848, p.1297

${ }^{43}$ Economist, October 21, 1848, p.1187

${ }^{44}$ Gale, Letter, p.5.

${ }^{45}$ McCartney and Arnold, "Capital Clamours".

${ }^{46}$ Campbell, "Myopic rationality".

${ }^{47}$ Campbell, "Myopic rationality".

${ }^{48}$ Campbell, "Deriving the Railway Mania"

${ }^{49}$ Railway Times, September 21, 1844, p.1078

${ }^{50}$ Economist, November 8, 1845, p.1101

${ }^{51}$ Economist, October 21, 1848, p.1187

${ }^{52}$ Railway Times, October 14, 1843, p.1127

${ }^{53}$ The Economist, November 4, 1848, p.1241

${ }^{54}$ Jackman, Development of Transportation, p.599.

${ }^{55}$ Return on Capital Employed is calculated from data in Slaughter, Railway Intelligence.

${ }^{56}$ Slaughter, Railway Intelligence

${ }^{57}$ Parliamentary Papers, "Railways. Return, showing the number of passengers conveyed on all the railways in England and Wales, Scotland, and Ireland, respectively, during the half-year ending the 30th June 1850", and Parliamentary Papers, "Railways. Return, showing the number of passengers conveyed on all the railways in England and Wales, Scotland, and Ireland, respectively, during the half-year ended the 31st December 1850."

${ }^{58}$ Parliamentary Papers. "Railways. Return, showing for each railway company the amount of capital and loans which the company has been authorized to raise by acts passed previous to and in 1850; the amount of share capital actually paid up on the 31st day of December 1850."

${ }^{59}$ This is consistent with Arnold and McCartney "Rates of Return" pp.53-54 who find that over their sample period, between 1830 and 1912, 'profit levels were consistently and positively related to size across the entire period for which disaggregated figures are available, revealing the existence of clear and consistent, albeit modest, returns to scale'

${ }^{60}$ Crafts et al. "Were British Railway Companies"; Crafts et al. "Total Factor Productivity Growth'; Mitchell et al., "How Good Was the Profitability".

${ }^{61}$ Acheson et al. "Corporate Ownership" report that the top five shareholders of the Great Western Railway only controlled 5.8 per cent of the company's capital in 1843.

${ }^{62}$ Although the five-firm concentration ratio did not change much over the 1844-1912 period (Arnold and McCartney, "Rates of Returns", p. 50, there was less competition after the 1850s because many journeys were monopolistic (Crafts et al. "Were British Railway Companies", p.861)

${ }^{63}$ Arnold and McCartney, "Rates of Returns", p. 57. 


\section{References}

Acheson, Graeme G., Charles R. Hickson, John D. Turner and Qing Ye. "Rule Britannia!: British Stock Market Returns, 1825-1870." Journal of Economic History 69 (2009): 1106-36.

Acheson, Graeme G., Gareth Campbell, John D. Turner and Nadia Vanteeva. "Corporate Ownership and Control in Victorian Britain." Economic History Review (2014): forthcoming.

Arnold, Anthony J. and Sean McCartney. "Rates of Return, Concentration Levels and Strategic Change in the British Railway Industry." Journal of Transport History 26 (2005): 41-60.

Barnes, Donald G. A History of the Corn Laws from 1660 to 1846, London: G. Routledge and Sons, 1930.

Bradshaw, G. Bradshaw's Monthly General Railway and Steam Navigation Guide, London: Bradshaw's Railway Information Office, 1843.

Bradshaw, G. Bradshaw's Monthly General Railway and Steam Navigation Guide, London: Bradshaw's Railway Information Office, 1850.

Braggion, Fabio and Lyndon Moore. "Dividend Policies in an Unregulated Market: The London Stock Exchange 1895-1905.” Review of Financial Studies 24 (2011): 2935-73.

Bryer, Rob A. "Accounting for the 'Railway Mania' of 1845 - A Great Railway Swindle?", Accounting, Organisations and Society 16 (1991): 439-486.

Cain, P. J. "Railways, 1870-1914: The Maturity of the Private System." pp. 92-133 in Michael J. Freeman and Derek H. Aldcroft, eds., Transport in Victorian Britain. Manchester: Manchester University Press, 1988.

Campbell, Gareth., "Myopic Rationality in a Mania." Explorations in Economic History 49 (2012): 75-91.

Campbell, Gareth. "Deriving the railway mania." Financial History Review 20.01 (2013): 1-27.

Campbell, Gareth, John D. Turner, and Clive B. Walker. "The role of the media in a bubble." Explorations in Economic History 49.4 (2012): 461-481.

Casson, Mark. The World's First Railway System: Enterprise, Competition, and Regulation on the Railway Network in Victorian Britain. Oxford: Oxford University Press, 2009.

Chandler, Alfred D. Scale and Scope: The Dynamics of Industrial Capitalism. Cambridge, MA: Belknap Press, 1990. 
Cheffins, Brian R., "History and the Global Corporate Governance Revolution: The UK Perspective." Business History 43 (2001): 87-118.

Cheffins, Brian R. Corporate Ownership and Control: British Business Transformed. Oxford: Oxford University Press, 2008.

Crafts, Nicholas, Terence C. Mills, T. C., and Abay Mulatu. "Total Factor Productivity Growth on Britain's Railways, 1852-1912: A Reappraisal of the Evidence." Explorations in Economic History 44 (2007):608-34.

Crafts, Nicholas, Timothy Leunig, and Abay Mulatu,. "Were British Railway Companies Well Managed in the Early Twentieth Century?' Economic History Review61 (2008): 842-66.

Eatwell, John. "Useful Bubbles.” Contributions to Political Economy 23 (2004): 3547.

Elbaum, Bernard and William Lazonick. "The Decline of the British Economy: An Institutional Perspective." Journal of Economic History 44 (1984):567-83.

EDINA. England and Wales Registration Districts 1851, http://edina.ac.uk, 2011

Foreman-Peck, James and Les Hannah. "Extreme Divorce: The Managerial Revolution in UK Companies before 1914." Economic History Review 65 (2012): 1217-38.

Francis, John. A History of the English Railway: Its Social Relations and Revelations. 1820-1845, London: Longman, Brown, Green, and Longmans, 1851.

Gale, Charles J. A Letter to the Right Hon. the Earl of Dalhousie, President of the Board of Trade, on Railway Legislation. London: John Murray, 1844.

Gayer, Arthur D., W. W. Rostow and Anna Jacobson Schwartz. The Growth and Fluctuation of the British Economy. Oxford: Clarendon Press, 1953.

GENUKI Gazetteer. http://www.genuki.org.uk/big/Gazetteer/, 2011

Gourvish, Terry R. "Railways 1830-70: The Formative Years." In Transport in Victorian Britain, edited by Michael J. Freeman and Derek H. Aldcroft, 57-91. Manchester: Manchester University Press, 1988.

Grossman, Richard S. "New Indices of British Equity Prices, 1870-1913.” Journal of Economic History 62 (2002): 121-46.

Hannah, Les. "The Divorce of Ownership from Control from 1900: Re-calibrating Imagined Global Historical Trends.” Business History 49 (2007): 404-38. 
Hawke, G. R. "Pricing Policy of Railways in England and Wales." In Railways in the Victorian Economy: Studies in Finance and Economic Growth, edited by M. C. Reed, 76-110. New York: Augustus M. Kelley, 1968.

Hyndman, H. M. Commercial Crises of the Nineteenth Century. New York: Augustus M. Kelley, 1968 [first pub. 1892].

Irving, R. J. "The Profitability and Performance of Britain's Railways, 1870-1914." Economic History Review, 31 (1978): 46-66.

Jackman, William T. The Development of Transportation in Modern England. London: Cass, 1966.

Kenwood, A. G. "Railway Investment in Britain, 1825-1875." Economica 32 (1965): 313-22.

Kindleberger, Charles P. A Financial History of Western Europe. London: George Allen and Unwin, 1984.

Kirk, J., Advanced Dijkstra's Minimum Path Algorithm for MATLAB, http://www.mathworks.com/matlabcentral/fileexchange/20025, 2008

Kostal, Rande W. Law and English Railway Capitalism. Oxford: Oxford University Press, 1994.

Leunig, T. "Time is Money: A Re-Assessment of the Passenger Social Savings from Victorian British Railways." The Journal of Economic History 66 (2006): 635-673

Lewin, Henry G. The Railway Mania and its Aftermath. Newton Abbot: David \& Charles, 1968 [first pub. 1936].

McCartney, Sean, and A. J. (Tony) Arnold. "Capital Clamours for Profitable Investment, Confidence Has Become Eager and May Shortly Become Blind': George Hudson and the 'Railway Mania' Extensions of the York and North Midland Railway." Journal of Industrial History 4 (2001): 94-116.

McCartney, Sean, and A. J. (Tony) Arnold. "The Railway Mania of 1845-1847: Market Irrationality or Collusive Swindle Based on Accounting Distortions?" Accounting, Auditing and Accountability Journal 16 (2003): 821-52.

McCloskey, D. N., "Did Victorian Britain Fail?" Economic History Review, 23 (1970): 446-59.

McCloskey, D. N. and L. Sandberg, "From Damnation to Redemption: Judgments on the Late Victorian Entrepreneur." Explorations in Economic History 9 (1971): 89108 .

Mann, H. B. and D. R. Whitney. "On a Test of Whether One of Two Random Variables is Stochastically Larger than the Other." The Annals of Mathematical Statistics 18, (1947):50-60 
Michie, Ranald C. The London Stock Exchange: A History. Oxford: Oxford University Press, 1999.

Miller, Robert C. B. Railway.com: Parallels Between the Early British Railways and the ICT Revolution. London: Institute of Economic Affairs, 2003.

Mitchell, Brian R. 'The Coming of the Railway and United Kingdom Economic Growth.' Journal of Economic History 24, no.3 (1964): 315-66.

Mitchell, Brian R., David Chambers and N. F. R. Crafts. "How Good Was the Profitability of British Railways, 1870-1912?" Economic History Review 64 (2011): 798-831.

Nairn, Alasdair. Engines that Move Markets: Technology Investing from Railroads to the Internet and Beyond. London: Wiley, 2002.

Odlyzko, Andrew. Collective Hallucinations and Inefficient Markets: The British Railway Mania of the 1840s. University of Minnesota, 2010.

Parliamentary Papers. "Fifth Report from the Select Committee on Railways; Together with the Minutes of Evidence, Appendix and Index." XI (1844).

Parliamentary Papers. "Railways. Return of the Number of Passengers Conveyed on all the Railways in the United Kingdom during the Half-Year Ending the 30th June 1849."' LIII, (1850).

Parliamentary Papers. "Railways. Return, Showing the Number of Passengers Conveyed on All the Railways in England and Wales, Scotland, and Ireland, Respectively, during the Half-Year Ending the 30th June 1850.” LI, (1851).

Parliamentary Papers. "Railways. Return, showing the number of passengers conveyed on all the railways in England and Wales, Scotland, and Ireland, respectively, during the half-year ended the 31 st December 1850.” LI (1851)

Parliamentary Papers. "Railways. Return, showing for each railway company the amount of capital and loans which the company has been authorized to raise by acts passed previous to and in 1850; the amount of share capital actually paid up on the 31st day of December 1850."

Pástor, Luboš and Pietro Veronesi. "Technological Revolutions and Stock Prices." American Economic Review 99 (2009): 1451-83.

Reed, Malcolm C. "Railways and the Growth of the Capital Market." In Railways in the Victorian Economy: Studies in Finance and Economic Growth, edited by Malcolm C. Reed, 162-83. New York: Augustus M. Kelley, 1968. 
Rutterford, Janette, David R. Green, Josephine Maltby and Alastair Owens. "Who Comprised the Nation of Shareholders? Gender and Investment in Great Britain, c.1870-1935." Economic History Review 64 (2011): 157-87.

Simmons, Jack. The Railway in England and Wales, 1830-1914, vol.1, Leicester: Leicester University Press, 1978.

Slaughter, M. Railway Intelligence, Published Under the Authority of the Stock Exchange. London: W.H. Smith and Son, 1850

Vision of Britain Historical Units Database. http://www.visionofbritain.org.uk, 2011

Wilson, John F. British Business History, 1720-1994. Manchester: Manchester University Press, 1995. 
FIGURE 1: RAILWAY MAP OF GREAT BRITAIN IN 1843 AND 1850

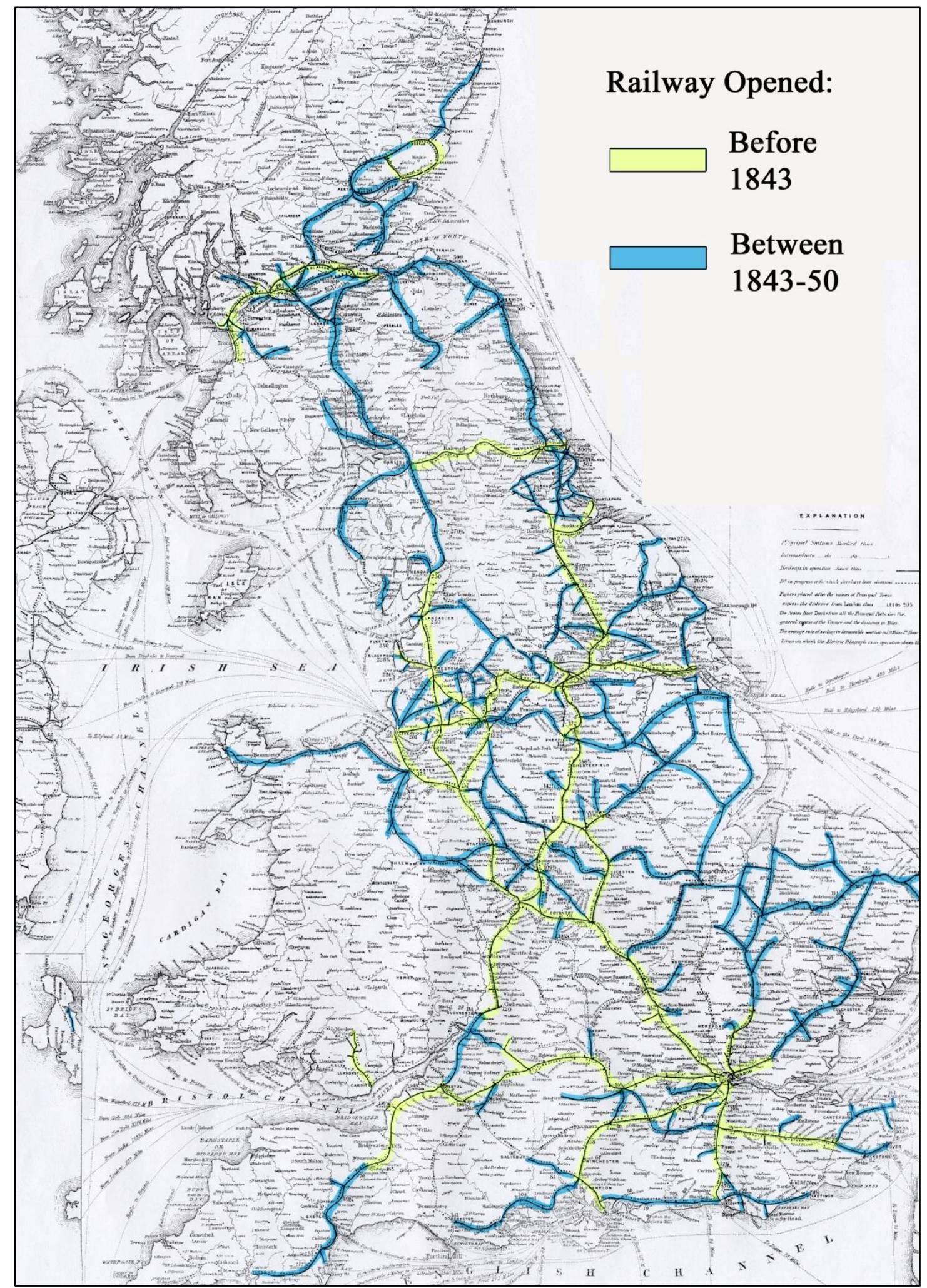

Sources: Reproduction of map included in Bradshaw's Monthly General Railway and Steam Navigation Guide, adapted with colouring based on information in timetables within the guide. 
FIGURE 2: COMPANY PROMOTION ADVERTS IN RAILWAY TIMES

AND RAILWAY SHARE INDEX, 1843-50

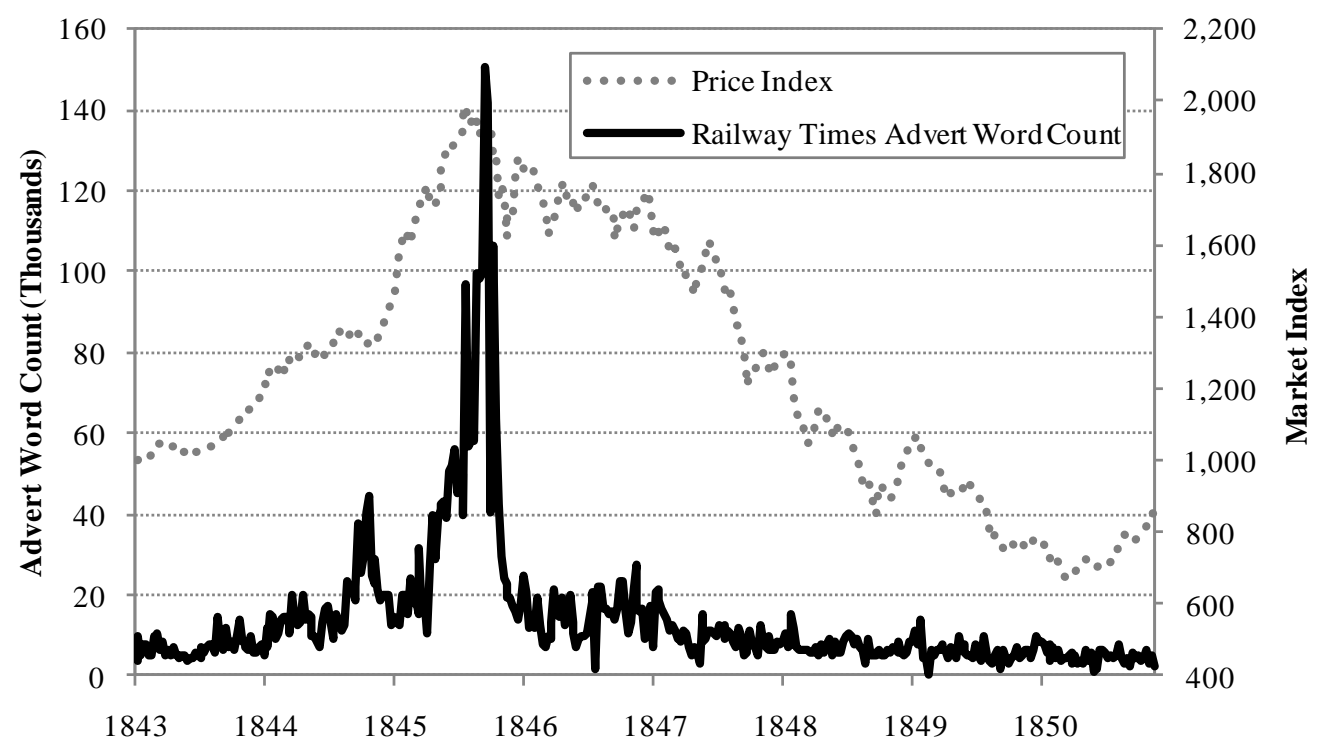

Sources: Word count of adverts was obtained by scanning in all company adverts in the Railway Times and running the scans through the Linguistic Inquiry and Word Count software. The index calculated from weekly share price tables in Railway Times. 
FIGURE 3: TOTAL PAR VALUE OF RAILWAYS, 1825-70

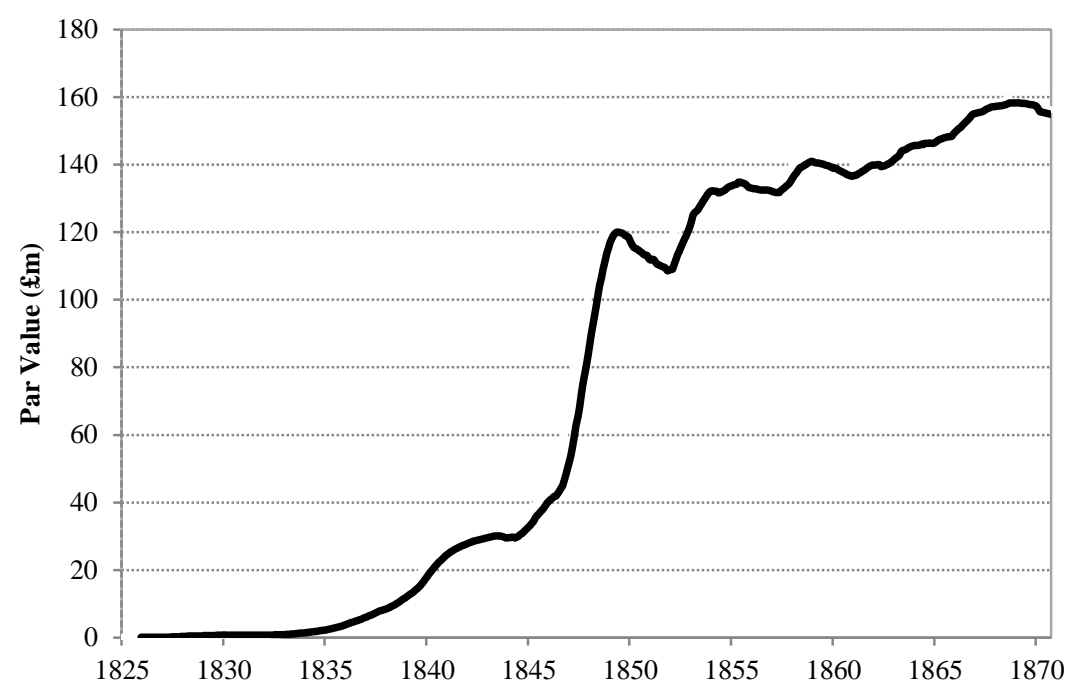

Sources: Course of the Exchange, 1825-70 and Acheson et al., "Rule Britannia".

Notes: This is a 12-month moving average of total par value of British railways traded on the London Stock Exchange. 
FIGURE 4: ANNUAL RAILWAY DIVIDENDS, 1832-70

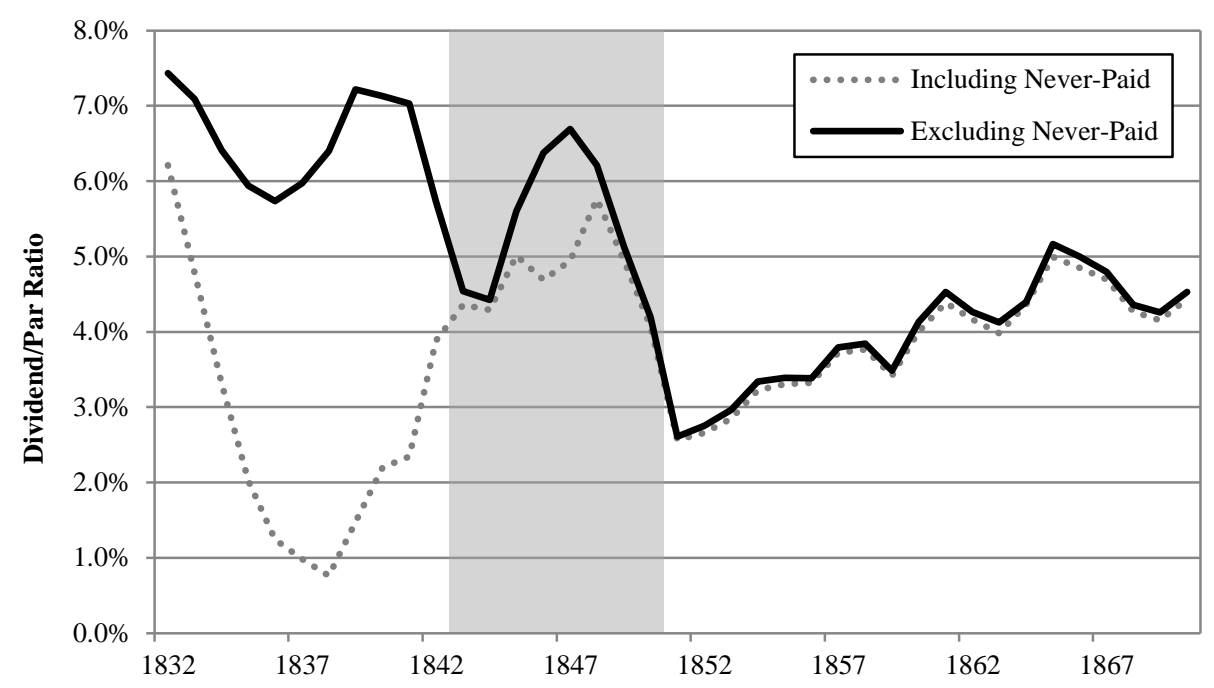

Source: Course of the Exchange, 1832-70.

Notes: Railway dividend/par index calculated as sum of dividends paid by railway companies divided by sum of par value of railway companies. 
FIGURE 5: RAILWAY SECURITIES LISTED ON LONDON STOCK EXCHANGE AND RAILWAY SHARE INDEX, 1843-50

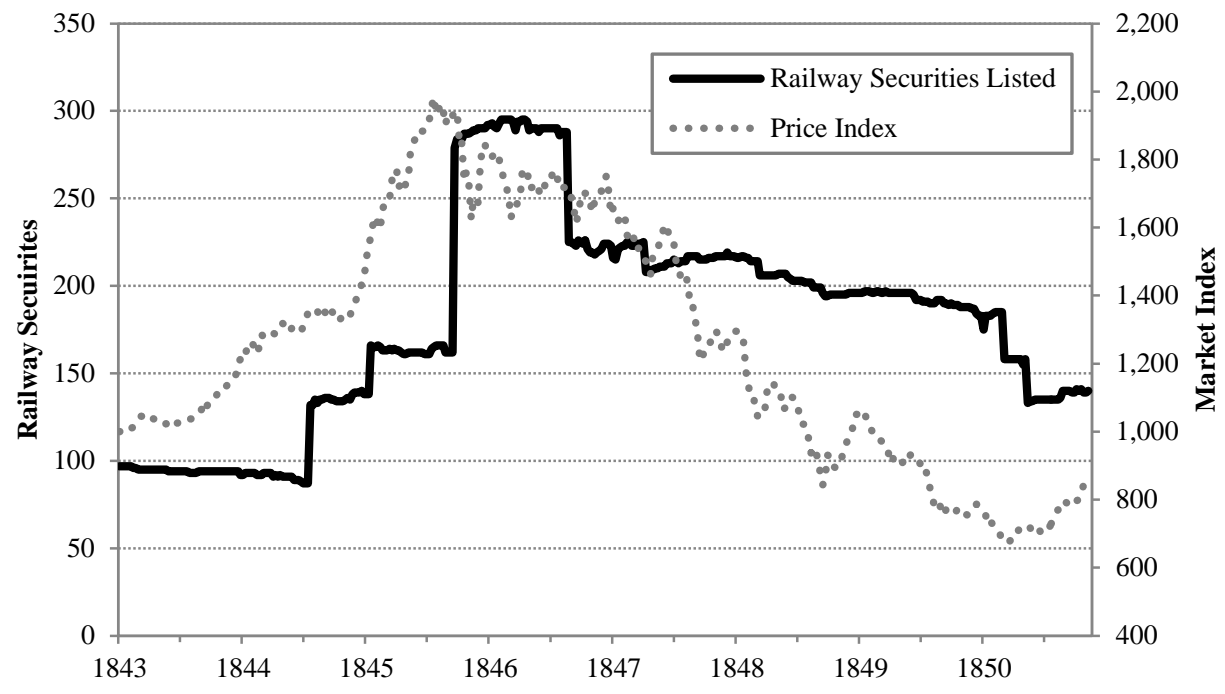

Sources: Calculated from weekly share price tables in Railway Times, 1843-50. 
TABLE 1: DESCRIPTIVE STATISTICS OF DISTRICTS WITH

RAILWAY STATIONS IN 1843 AND 1850

\begin{tabular}{rrrr} 
All lines & 1843 & New & All lines \\
in 1843 & districts & districts & in 1850 \\
\hline
\end{tabular}

Districts

188

188

238

426

Totals

Population

Mileage

Stations

$7,556,592$
1,505
339

30,068

121.3

11.0

3.0
$6,229,892$

2,456

688

$14,605,685$

2,568

705

114.2

6.6

1.0
2,355

7.1

4.4

2.0
20,689

73.4

8.1

2.0

$-7,024$

$-4,796$

$-40.8$

1.5

1.0

Mileage

Stations

Significance of Mann-Whitney Tests Comparing Sample with 1843 Sample

Population

Pop $/ \mathrm{km}^{2}$ (Eng\&Wales)

$\begin{array}{ccc} & * * * & * * \\ & * * * & * * * \\ * * * & * * * & * * * \\ * * * & * * * & * * *\end{array}$

Stations

Notes: List of railway stations and mileage data obtained from Bradshaw's Monthly General Railway and Steam Navigation Guide. Registration districts for each station found by using the 1851 Census Index to the Names of the Parishes, Townships, and Places in the Population tables of Great Britain and supplemented with the GENUKI Gazetteer and the Vision of Britain historical units database. Population of each district, at each time, was calculated from the 1851 Census by taking the reported 1841 and 1851 populations for each district and determining the average annual change, to estimate the populations in 1843 and 1850. Population density based on England and Wales, using data on the area of registration districts obtained from EDINA. Mileage per district calculated by assuming a particular segment of railway was equally divided between the districts which that segment connected. Mann-Whitney tests have a null hypothesis that the samples are drawn from the same population, whilst the alternative hypothesis is that the probability of an observation from one sample exceeding an observation from a second sample is not equal to 0.5 . Significance given by $* * * p<0.01, * * \mathrm{p}<0.05$. 
TABLE 2: MILEAGE BETWEEN SELECTED RAILWAY STATIONS IN 1843 IF SHORTEST ROUTE CHOSEN

\begin{tabular}{|c|c|c|c|c|c|c|c|c|c|}
\hline \multicolumn{10}{|c|}{ Panel A: Full 1843 Railway Network } \\
\hline & Birmingham & Brighton & Bristol & Derby & Liverpool & London & Manchester & Southampton & York \\
\hline Birmingham & 0.0 & 163.0 & 230.8 & 41.3 & 98.5 & 112.5 & 84.8 & 192.5 & 128.8 \\
\hline Brighton & 163.0 & 0.0 & 168.8 & 184.3 & 261.5 & 50.5 & 247.8 & 130.5 & 271.8 \\
\hline Bristol & 230.8 & 168.8 & 0.0 & 252.0 & 329.3 & 118.3 & 315.5 & 198.3 & 339.5 \\
\hline Derby & 41.3 & 184.3 & 252.0 & 0.0 & 139.8 & 133.8 & 115.3 & 213.8 & 87.5 \\
\hline Liverpool & 98.5 & 261.5 & 329.3 & 139.8 & 0.0 & 211.0 & 31.5 & 291.0 & 107.8 \\
\hline London & 112.5 & 50.5 & 118.3 & 133.8 & 211.0 & 0.0 & 197.3 & 80.0 & 221.3 \\
\hline Manchester & 84.8 & 247.8 & 315.5 & 115.3 & 31.5 & 197.3 & 0.0 & 277.3 & 76.3 \\
\hline Southampton & 192.5 & 130.5 & 198.3 & 213.8 & 291.0 & 80.0 & 277.3 & 0.0 & 301.3 \\
\hline York & 128.8 & 271.8 & 339.5 & 87.5 & 107.8 & 221.3 & 76.3 & 301.3 & 0.0 \\
\hline \multicolumn{10}{|c|}{ Panel B: Without Blisworth to Roade Railway Segment } \\
\hline & Birmingham & Brighton & Bristol & Derby & Liverpool & London & Manchester & Southampton & York \\
\hline Birmingham & 0.0 & N/A & N/A & 41.3 & 98.5 & N/A & 84.8 & N/A & 128.8 \\
\hline Brighton & N/A & 0.0 & 168.8 & N/A & N/A & 50.5 & N/A & 130.5 & N/A \\
\hline Bristol & N/A & 168.8 & 0.0 & N/A & N/A & 118.3 & N/A & 198.3 & N/A \\
\hline Derby & 41.3 & N/A & N/A & 0.0 & 139.8 & N/A & 115.3 & N/A & 87.5 \\
\hline Liverpool & 98.5 & N/A & N/A & 139.8 & 0.0 & N/A & 31.5 & N/A & 107.8 \\
\hline London & N/A & 50.5 & 118.3 & N/A & N/A & 0.0 & N/A & 80.0 & N/A \\
\hline Manchester & 84.8 & N/A & N/A & 115.3 & 31.5 & N/A & 0.0 & N/A & 76.3 \\
\hline Southampton & N/A & 130.5 & 198.3 & N/A & N/A & 80.0 & N/A & 0.0 & N/A \\
\hline York & 128.8 & N/A & N/A & 87.5 & 107.8 & N/A & 76.3 & N/A & 0.0 \\
\hline
\end{tabular}

Number of Routes Affected: 40

Median Increase in Mileage: No Substitute Available

\begin{tabular}{lccccccccc}
\hline \multicolumn{7}{c}{ Panel C: Without Sawley to Long Eaton Junction Railway Segment } \\
\hline & Birmingham & Brighton & Bristol & Derby & Liverpool & London & Manchester & Southampton & York \\
Birmingham & 0.0 & 163.0 & 230.8 & 41.3 & 98.5 & 112.5 & 84.8 & 192.5 & 128.8 \\
Brighton & 163.0 & 0.0 & 168.8 & 204.3 & 261.5 & 50.5 & 247.8 & 130.5 & 291.8 \\
Bristol & 230.8 & 168.8 & 0.0 & 272.0 & 329.3 & 118.3 & 315.5 & 198.3 & 359.5 \\
Derby & 41.3 & 204.3 & 272.0 & 0.0 & 139.8 & 153.8 & 115.3 & 233.8 & 87.5 \\
Liverpool & 98.5 & 261.5 & 329.3 & 139.8 & 0.0 & 211.0 & 31.5 & 291.0 & 107.8 \\
London & 112.5 & 50.5 & 118.3 & 153.8 & 211.0 & 0.0 & 197.3 & 80.0 & 241.3 \\
Manchester & 84.8 & 247.8 & 315.5 & 115.3 & 31.5 & 197.3 & 0.0 & 277.3 \\
Southampton & 192.5 & 130.5 & 198.3 & 233.8 & 291.0 & 80.0 & 277.3 & 76.3 \\
York & 128.8 & 291.8 & 359.5 & 87.5 & 107.8 & 241.3 & 76.3 & 0.0 & 321.3
\end{tabular}

Number of Routes Affected: 16

Median Increase in Mileage: 20 miles (8.5\% of original journey times)

Notes: Mileage between railway stations calculated using Djikstra shortest path algorithm, with data on the mileage between adjacent stations obtained from Bradshaw's Monthly General Railway and Steam Navigation Guide. Journeys affected by the removal of segments are highlighted in Panels B and C. 
TABLE 3: RAILWAY SEGMENTS WITH NO SUBSTITUTE AVAILABLE

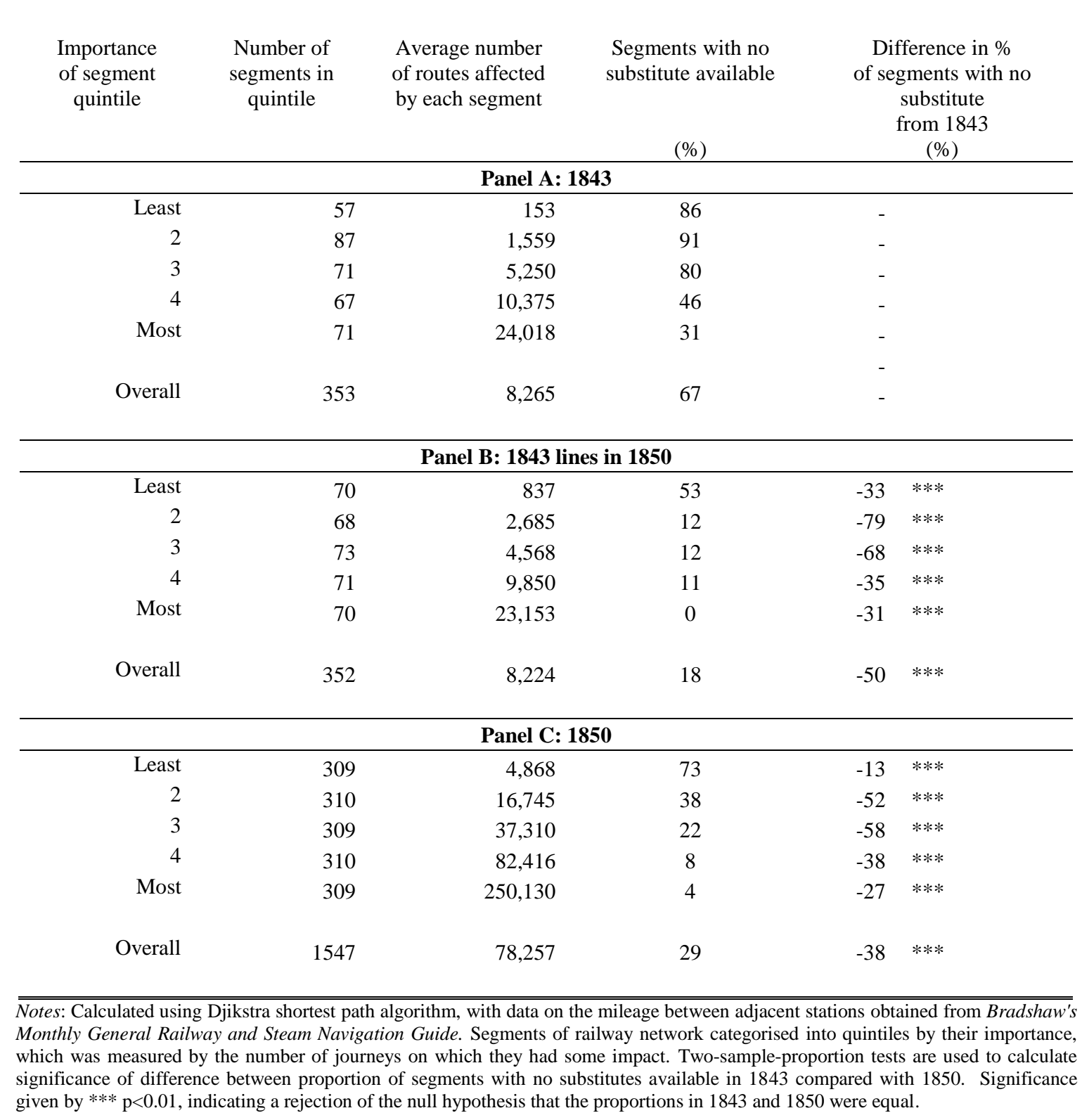


TABLE 4: INCREASE IN RAILWAY JOURNEY TIMES IF BEST SUBSTITUTE TAKEN INSTEAD

\begin{tabular}{|c|c|c|c|c|c|c|c|c|c|c|c|c|c|c|c|c|}
\hline \multirow{3}{*}{$\begin{array}{c}\text { Importance } \\
\text { of Segment } \\
\text { Quintile }\end{array}$} & \multirow{3}{*}{$\begin{array}{l}\text { Number of } \\
\text { Segments } \\
\text { in Quintile }\end{array}$} & \multirow{3}{*}{$\begin{array}{c}\text { Average } \\
\text { Number of } \\
\text { Routes } \\
\text { Affected }\end{array}$} & \multirow{3}{*}{$\begin{array}{c}\text { \% of } \\
\text { segments } \\
\text { with a } \\
\text { substitute } \\
\text { available }\end{array}$} & \multicolumn{11}{|c|}{$\begin{array}{c}\text { Median Increase in Journey Mileage (as a Percentage of Original Journey Length) Required by Taking } \\
\text { the Best Substitute, for those segments where substitute is available }\end{array}$} & \multirow{3}{*}{$\begin{array}{c}\text { Difference } \\
\text { In Sample } \\
\text { Median } \\
\text { With 1843 } \\
\text { Median } \\
(\%)\end{array}$} & \multirow{3}{*}{$\begin{array}{c}\text { Mann- } \\
\text { Whitney } \\
\text { test } \\
\text { comparing } \\
\text { sample } \\
\text { with } 1843 \\
\text { sample }\end{array}$} \\
\hline & & & & \multicolumn{11}{|c|}{ Length of original journeys in miles: } & & \\
\hline & & & & $<\mathbf{1 0}$ & $10-25$ & $25-50$ & $50-75$ & $75-100$ & $\begin{array}{l}100- \\
150\end{array}$ & $\begin{array}{l}150- \\
200\end{array}$ & $\begin{array}{l}200- \\
250\end{array}$ & $\begin{array}{l}250- \\
300\end{array}$ & $>\mathbf{3 0 0}$ & $\begin{array}{c}\text { All } \\
\text { lengths }\end{array}$ & & \\
\hline \multicolumn{17}{|c|}{ Panel A: 1843} \\
\hline Least & 57 & 153 & 14 & 689 & 131 & 11 & - & - & - & - & - & - & - & 96 & - & \\
\hline 2 & 87 & 1,559 & 9 & 674 & 130 & 56 & 27 & 19 & 13 & 8 & 4 & 3 & 3 & 14 & - & \\
\hline 3 & 71 & 5,250 & 20 & 1483 & 438 & 137 & 58 & 45 & 21 & 17 & 14 & 4 & 2 & 21 & - & \\
\hline 4 & 67 & 10,375 & 54 & 1650 & 520 & 208 & 63 & 49 & 23 & 17 & 6 & 5 & 4 & 23 & - & \\
\hline Most & 71 & 24,018 & 69 & 3049 & 1022 & 415 & 196 & 103 & 37 & 29 & 23 & 19 & 16 & 22 & - & \\
\hline Overall & 353 & 8,265 & 33 & 1765 & 474 & 154 & 64 & 64 & 25 & 18 & 9 & 7 & 5 & 22 & - & \\
\hline \multicolumn{17}{|c|}{ Panel B: 1843 lines in 1850} \\
\hline Least & 70 & 837 & 47 & 1049 & 252 & 47 & 51 & 22 & 16 & 11 & 5 & 5 & 3 & $9 \%$ & $-86 \%$ & **** \\
\hline 2 & 68 & 2,685 & 88 & 1061 & 302 & 77 & 29 & 19 & 16 & 9 & 5 & 3 & 2 & $10 \%$ & $-4 \%$ & \\
\hline 3 & 73 & 4,568 & 88 & 1204 & 270 & 73 & 27 & 15 & 13 & 9 & 6 & 4 & 4 & $10 \%$ & $-11 \%$ & \\
\hline 4 & 71 & 9,850 & 89 & 755 & 204 & 54 & 19 & 12 & 8 & 6 & 3 & 2 & 2 & $5 \%$ & $-18 \%$ & $* * *$ \\
\hline Most & 70 & 23,153 & 100 & 1663 & 509 & 190 & 73 & 31 & 21 & 14 & 9 & 7 & 5 & $9 \%$ & $-12 \%$ & $* * *$ \\
\hline Overall & 352 & 8,224 & 82 & 1026 & 267 & 74 & 30 & 19 & 15 & 10 & 6 & 4 & 3 & $9 \%$ & $-12 \%$ & $* * *$ \\
\hline Difference in & le median with & 43 median & & -739 & -206 & -80 & -34 & $-44 \%$ & $-10 \%$ & $-8 \%$ & -4 & -3 & -3 & -12 & & \\
\hline Mann-Whitne & t comparing san & le with 1843 sa & & $* * *$ & $* * *$ & $* * *$ & $* * *$ & $* * *$ & $* * *$ & $* * *$ & $* * *$ & $* * *$ & $* * *$ & $* * *$ & & \\
\hline \multicolumn{17}{|c|}{ Panel C: 1850} \\
\hline Least & 309 & 4,868 & 27 & 484 & 107 & 25 & 12 & 7 & 4 & 3 & 3 & 2 & 2 & $5 \%$ & $-91 \%$ & $* * *$ \\
\hline 2 & 310 & 16,745 & 62 & 668 & 153 & 37 & 18 & 12 & 8 & 6 & 4 & 4 & 2 & $6 \%$ & $-8 \%$ & $* *$ \\
\hline 3 & 309 & 37,310 & 78 & 1096 & 286 & 78 & 33 & 25 & 12 & 8 & 6 & 4 & 4 & $7 \%$ & $-14 \%$ & $* * *$ \\
\hline 4 & 310 & 82,416 & 92 & 1415 & 393 & 112 & 45 & 29 & 16 & 8 & 4 & 3 & 3 & $7 \%$ & $-17 \%$ & $* * *$ \\
\hline Most & 309 & 250,130 & 96 & 843 & 229 & 69 & 44 & 25 & 16 & 10 & 7 & 6 & 3 & $7 \%$ & $-15 \%$ & $* * *$ \\
\hline Overall & 1547 & 78,257 & 71 & 959 & 238 & 67 & 30 & 20 & 11 & 7 & 5 & 4 & 3 & $6 \%$ & $-15 \%$ & $* * *$ \\
\hline Difference in : & le median with & 43 median & & -806 & -236 & -86 & -34 & $-44 \%$ & $-14 \%$ & $-11 \%$ & -5 & -4 & -3 & -15 & & \\
\hline Mann-Whitne & t comparing san & e with 1843 sa & & $* * *$ & $* * *$ & $* * *$ & $* * *$ & $* * *$ & $* * *$ & $* * *$ & $* * *$ & $* * *$ & $* * *$ & $* * *$ & & \\
\hline
\end{tabular}

Notes: Calculated using Djikstra shortest path algorithm, with data on the mileage between adjacent stations from Bradshaw's Monthly General Railway and Steam Navigation Guide. Segments of railway network categorised into quintiles by their importance, which was measured by the number of journeys on which they had some impact. Journeys categorised according to their length. For each segment where a substitute was 
TABLE 5: INDUSTRY MILEAGE AND RECEIPTS

\begin{tabular}{ccccccccc}
\hline \hline & & & & & \multicolumn{3}{c}{ Growth $(\%)$} \\
\cline { 5 - 8 } Year & Miles & Goods & Passenger & Number of \\
Open & Receipts & Receipts & Receipts & Passengers \\
\hline 1842 & 2,069 & $1,698,307$ & $3,082,760$ & $24,492,957$ & & & \\
$\ldots$ & $\ldots$ & $\ldots$ & $\ldots$ & $\ldots$ & & & \\
1845 & 2,343 & $2,233,373$ & $3,976,311$ & $33,791,253$ & 13.2 & 29.0 & 38.0 \\
1846 & 2,765 & $2,840,353$ & $4,795,215$ & $43,790,083$ & 18.0 & 20.6 & 29.6 \\
1847 & 3,603 & $3,382,883$ & $5,148,002$ & $51,352,163$ & 30.3 & 7.4 & 17.3 \\
1848 & 4,478 & $4,213,169$ & $5,720,382$ & $57,965,070$ & 24.3 & 11.1 & 12.9 \\
1849 & 5,447 & $5,094,925$ & $6,105,975$ & $60,398,159$ & 21.6 & 6.7 & 4.2 \\
1850 & 6,308 & $5,942,246$ & $6,465,570$ & $66,839,375$ & 15.8 & 5.9 & 10.7
\end{tabular}

Sources: Parliamentary Papers (1844), XI, 'Fifth report from the Select Committee on Railways; together with the minutes of evidence, appendix and index,' Appendix 2, p.8. Parliamentary Papers (1850), LIII, p.257, 'Railways. Return of the number of passengers conveyed on all the railways in the United Kingdom during the half-year ending the 30th June 1849; showing the different classes, the receipts from each class, and from goods, \&c.; compiled from returns made to the Commissioners of Railways by each railway company, in pursuance of the provisions of the act $3 \& 4$ Vict. c. 97 ; also, the number of miles of railway open, and a comparative statement of the traffic, for the five years ending 30th June 1845, 1846, 1847, 1848 and 1849.'Parliamentary Papers (1851), LI, p.229, 'Railways. Return, showing the Number of Passengers Conveyed on All the Railways in England and Wales, Scotland, and Ireland, respectively, during the half-year ending the 30th June 1850'.Notes: Includes Ireland. 
TABLE 6: COMPANY MILEAGE, COMPETITION AND PERFORMANCE IN 1843 AND 1850

\begin{tabular}{|c|c|c|c|c|c|c|c|c|c|c|c|c|c|}
\hline & \multirow[b]{2}{*}{$\begin{array}{c}\text { Mileage } \\
\text { Open }\end{array}$} & \multirow[b]{2}{*}{ Pop/Mile } & \multicolumn{2}{|c|}{$\%$ of Routes with Monopoly } & \multirow[b]{2}{*}{$\begin{array}{l}\% \text { Increase in mileage } \\
\text { from alternative route }\end{array}$} & \multicolumn{3}{|c|}{$\begin{array}{c}\text { Average Fares Per } \\
\text { Mile } \\
\end{array}$} & \multirow[b]{2}{*}{$\begin{array}{l}\text { Receipt/ } \\
\text { Mile (£) }\end{array}$} & \multirow[b]{2}{*}{$\begin{array}{c}\text { Expenses/ } \\
\text { Mile (£) }\end{array}$} & \multirow[b]{2}{*}{$\begin{array}{l}\text { Profit/ } \\
\text { Mile (£) }\end{array}$} & \multirow[b]{2}{*}{$\begin{array}{c}\text { Return on } \\
\text { Capital (\%) }\end{array}$} & \multirow[b]{2}{*}{$\begin{array}{c}\text { Dividend/ } \\
\text { Par }\end{array}$} \\
\hline & & & $\begin{array}{c}\text { From Own } \\
\text { Lines \& } \\
\text { Other } \\
\text { Companies }\end{array}$ & $\begin{array}{l}\text { From Other } \\
\text { Companies }\end{array}$ & & $\begin{array}{c}1 \mathrm{st} \\
\text { Class } \\
\end{array}$ & $\begin{array}{l}\text { 2nd } \\
\text { Class }\end{array}$ & $\begin{array}{c}\text { 3rd } \\
\text { Class }\end{array}$ & & & & & \\
\hline $\begin{array}{l}\text { Average for established } \\
\text { companies in } 1843 \\
(\mathrm{~N}=44)\end{array}$ & 36 & 11,761 & 72 & 85 & 30 & 2.6 & 1.8 & 1.2 & 3,603 & 1,792 & 1,811 & 4.7 & 4.8 \\
\hline $\begin{array}{l}\text { Average for established } \\
\text { companies in } 1850 \\
(\mathrm{~N}=25)\end{array}$ & 153 & 7,013 & 32 & 66 & 9 & 2.2 & 1.5 & 0.9 & 2,559 & 1,328 & 1,231 & 3.3 & 2.5 \\
\hline $\begin{array}{l}\text { Average for new } \\
\text { companies in } 1850 \\
(\mathrm{~N}=37)\end{array}$ & 40 & 7,636 & 63 & 82 & 6 & 2.2 & 1.6 & 0.9 & 1,565 & 874 & 691 & 1.9 & 1.6 \\
\hline
\end{tabular}

Sources: Authors' calculations, and Parliamentary Papers (1844), XI, 'Fifth report from the Select Committee on Railways; together with the minutes of evidence, appendix and index,' Appendix 2, p.8-14, and Slaughter, M. (1850), 'Railway Intelligence, published under the authority of the Stock Exchange'.

Notes: Accounting data on receipts, expenses, profits and dividends only available for a subsample of companies (30 established companies in 1843,12 established companies in 1850, and 6 new companies in 1850). 
TABLE 7: COUNTERFACTUAL OF ALTERNATIVE POSSIBLE MANAGERIAL STRATEGIES FOR ESTABLISHED RAILWAYS IN 1850

\begin{tabular}{|c|c|c|c|c|c|c|c|c|c|c|c|c|c|}
\hline \multirow[b]{2}{*}{$\begin{array}{l}\text { Post-Merger } \\
\text { Company } \\
(1850)\end{array}$} & \multirow[b]{2}{*}{$\begin{array}{l}\text { Pre-Merger } \\
\text { Company } \\
(1843)\end{array}$} & \multicolumn{4}{|c|}{ No Mergers and No Expansion Between 1843 and 1850} & \multicolumn{4}{|c|}{ Mergers but No Expansion Between 1843 and 1850} & \multicolumn{4}{|c|}{ Mergers and Expansion Between 1843 and 1850} \\
\hline & & $\begin{array}{l}\text { Miles } \\
\text { Open }\end{array}$ & $\begin{array}{l}\text { Population } \\
\text { /Mile }\end{array}$ & $\begin{array}{l}\% \text { of Routes } \\
\text { with Monopoly } \\
\text { from External }\end{array}$ & $\begin{array}{l}\text { \% Increase } \\
\text { in Mileage } \\
\text { from }\end{array}$ & $\begin{array}{l}\text { Miles } \\
\text { Open }\end{array}$ & $\begin{array}{l}\text { Population } \\
\text { /Mile }\end{array}$ & $\begin{array}{l}\% \text { of Routes } \\
\text { with Monopoly } \\
\text { from External }\end{array}$ & $\begin{array}{l}\text { \% Increase } \\
\text { in Mileage } \\
\text { from }\end{array}$ & $\begin{array}{l}\text { Miles } \\
\text { Open }\end{array}$ & $\begin{array}{l}\text { Population } \\
\text { /Mile }\end{array}$ & $\begin{array}{l}\text { \% of Routes } \\
\text { with Monopoly } \\
\text { from External }\end{array}$ & $\begin{array}{l}\text { \% Increase } \\
\text { in Mileage } \\
\text { from }\end{array}$ \\
\hline \multirow{7}{*}{$\begin{array}{l}\text { London \& } \\
\text { North Western }\end{array}$} & London and Birmingham & 113 & 5,150 & Competition & 11 & 309 & 7,791 & Comperition & Amernative & 516 & 7,077 & Compertion & Amernative \\
\hline & Grand Junction & 83 & 9,802 & 10 & 3 & & & & & & & & \\
\hline & Liverpool Manchester & 32 & 22,705 & 13 & 2 & & & & & & & & \\
\hline & Manchester and Birmingham & 31 & 20,378 & 10 & 7 & & & & & & & & \\
\hline & North Union & 23 & 9,281 & 4 & 3 & & & & & & & & \\
\hline & Chester and Crewe & 21 & 7,287 & 11 & 25 & & & & & & & & \\
\hline & Aylesbury & 7 & 5,701 & 100 & 0 & & & & & & & & \\
\hline \multirow{5}{*}{ Midland } & North Midland & 74 & 5,862 & 12 & 5 & 232 & 5,898 & 19 & 6 & 451 & 5,195 & 37 & 5 \\
\hline & Midland Counties & 57 & 6,707 & 20 & 14 & & & & & & & & \\
\hline & Birmingham Gloucester & 55 & 7,129 & 24 & 30 & & & & & & & & \\
\hline & Birmingham Derby & 41 & 9,537 & 7 & 1 & & & & & & & & \\
\hline & Sheffield and Rotherham & 5 & 26,889 & 0 & 9 & & & & & & & & \\
\hline Eastern Counties & Northern and Eastern & $\begin{array}{l}29 \\
18\end{array}$ & $\begin{array}{r}4,596 \\
14620\end{array}$ & 42 & 6 & 46 & 7,716 & 34 & 23 & 330 & 3,648 & 93 & 4 \\
\hline York, Newc \& & GNER & 45 & 3,554 & 16 & 27 & 52 & 5,976 & 18 & 28 & 284 & 2,578 & 68 & 12 \\
\hline Berwick & Newcastle and NorthShields & 7 & 21,544 & 100 & 0 & & & & & & & & \\
\hline York \& & Hull and Selby & 39 & 4,035 & 32 & 12 & 63 & 4,589 & 14 & 16 & 251 & 1,924 & 63 & 1 \\
\hline N. Midland & York and North Midland & 24 & 7,438 & 6 & 17 & & & & & & & & \\
\hline \multirow{4}{*}{$\begin{array}{l}\text { Lancashire \& } \\
\text { Yorkshire }\end{array}$} & Manchester and Leeds & 55 & 14,452 & 22 & 12 & 107 & 8,888 & 24 & 7 & 239 & 9,393 & 31 & 4 \\
\hline & Preston and Wyre & 27 & 4,342 & 100 & 0 & & & & & & & & \\
\hline & Bolton and Preston & 15 & 10,054 & 11 & 1 & & & & & & & & \\
\hline & Manchester and Bolton & 10 & 33,782 & 8 & 2 & & & & & & & & \\
\hline L\&SW & London and South Western & 96 & 2,867 & 59 & 8 & 96 & 2,867 & 59 & 8 & 235 & 2,657 & 88 & 3 \\
\hline G. Western & Great Western & 190 & 3,694 & 67 & 4 & 145 & 4,105 & 50 & 5 & 228 & 3,684 & 66 & 2 \\
\hline \multirow{2}{*}{ South Eastern } & South Eastern & 46 & 2,351 & 100 & 0 & 50 & 5,285 & 100 & 0 & 212 & 3,093 & 94 & 7 \\
\hline & London and Greenwich & 4 & 43,845 & 100 & 0 & & & & & & & & \\
\hline Caledonian & Garnkirk and Glasgow & 11 & 43,314 & 4 & 3 & 11 & 43,314 & 4 & 3 & 165 & 6,136 & 29 & 12 \\
\hline MSL & Sheffield Ashton Manchester & 13 & 37,737 & 22 & 6 & 13 & 37,737 & 22 & 6 & 161 & 5,815 & 37 & 9 \\
\hline London, Brighton & London and Brighton & 46 & 4,705 & 36 & 12 & 57 & 4,841 & 43 & 12 & 160 & 4,142 & 61 & 11 \\
\hline Sth Coast & London and Croydon & 10 & 8,527 & 3 & 12 & & & & & & & & \\
\hline Lanc\&Carl. & Lancaster and Preston & 40 & 4,142 & 6 & 14 & 40 & 4,142 & 6 & 14 & 90 & 4,789 & 12 & 14 \\
\hline Edin\&Glas. & Edinburgh and Glasgow & 60 & 14,318 & 50 & 4 & 60 & 14,318 & 50 & 4 & 83 & 10,295 & 50 & 4 \\
\hline Glasgow, Pais, & Glasgow, Pais, Kilm \& Ayr & 48 & 13,489 & 100 & 0 & 51 & 12,688 & 100 & 0 & 75 & 8,572 & 100 & 0 \\
\hline Kilm \& Ayr & Paisley and Renfrew & 3 & 37,203 & 100 & 0 & & & & & & & & \\
\hline Aberdeen & Arbroath and Forfar & 15 & 6,364 & 100 & 53 & 15 & 6,364 & 100 & 53 & 64 & 2,026 & 100 & 48 \\
\hline Newc\&Carl & Newcastle and Carlisle & 59 & 3,783 & 63 & 8 & 59 & 3,783 & 63 & 8 & 60 & 3,721 & 64 & 8 \\
\hline Stock\&Darl & Stockton and Darlington & 19 & 5,301 & 79 & 11 & 19 & 5,301 & 79 & 11 & 50 & 3,380 & 79 & 11 \\
\hline Stock\&Hart & Stockton and Hartlepool & 15 & 3,442 & 100 & 0 & 15 & 3,442 & 100 & 0 & 47 & 2,269 & 39 & 14 \\
\hline Taff Vale & Taff Vale & 23 & 11,979 & 100 & 0 & 23 & 11,979 & 100 & 0 & 40 & 8,193 & 100 & 0 \\
\hline Scot Mid. & Dundee and Newtyle & 37 & 7,748 & 19 & 1 & 37 & 7,748 & 19 & 1 & 33 & 6,552 & 38 & 1 \\
\hline Dund\&Arb & Dundee and Arbroath & 13 & 14,935 & 57 & 1 & 13 & 14,935 & 57 & 1 & 17 & 11,351 & 57 & 1 \\
\hline BLC & Chester and Birkenhead & 16 & 6,935 & 100 & 0 & 16 & 6,935 & 100 & 0 & 16 & 12,255 & 100 & 0 \\
\hline Ardrossan & Ardrossan & 7 & 12,762 & 100 & 0 & 7 & 12,762 & 100 & 0 & 7 & 12,762 & 100 & 0 \\
\hline \multirow[t]{2}{*}{ Lond\&Blac } & London and Blackwall & 3 & 33,830 & 100 & 0 & 3 & 33,830 & 100 & 0 & 3 & 33,830 & 100 & 0 \\
\hline & Average & 36 & 13,139 & 46 & 8 & 61 & 11,089 & 55 & 9 & 153 & 7,013 & 66 & 7 \\
\hline
\end{tabular}


TABLE 8: RELATIONSHIP BETWEEN EXPANSION AND STRENGTH OF MONOPOLY WITHOUT EXPANSION

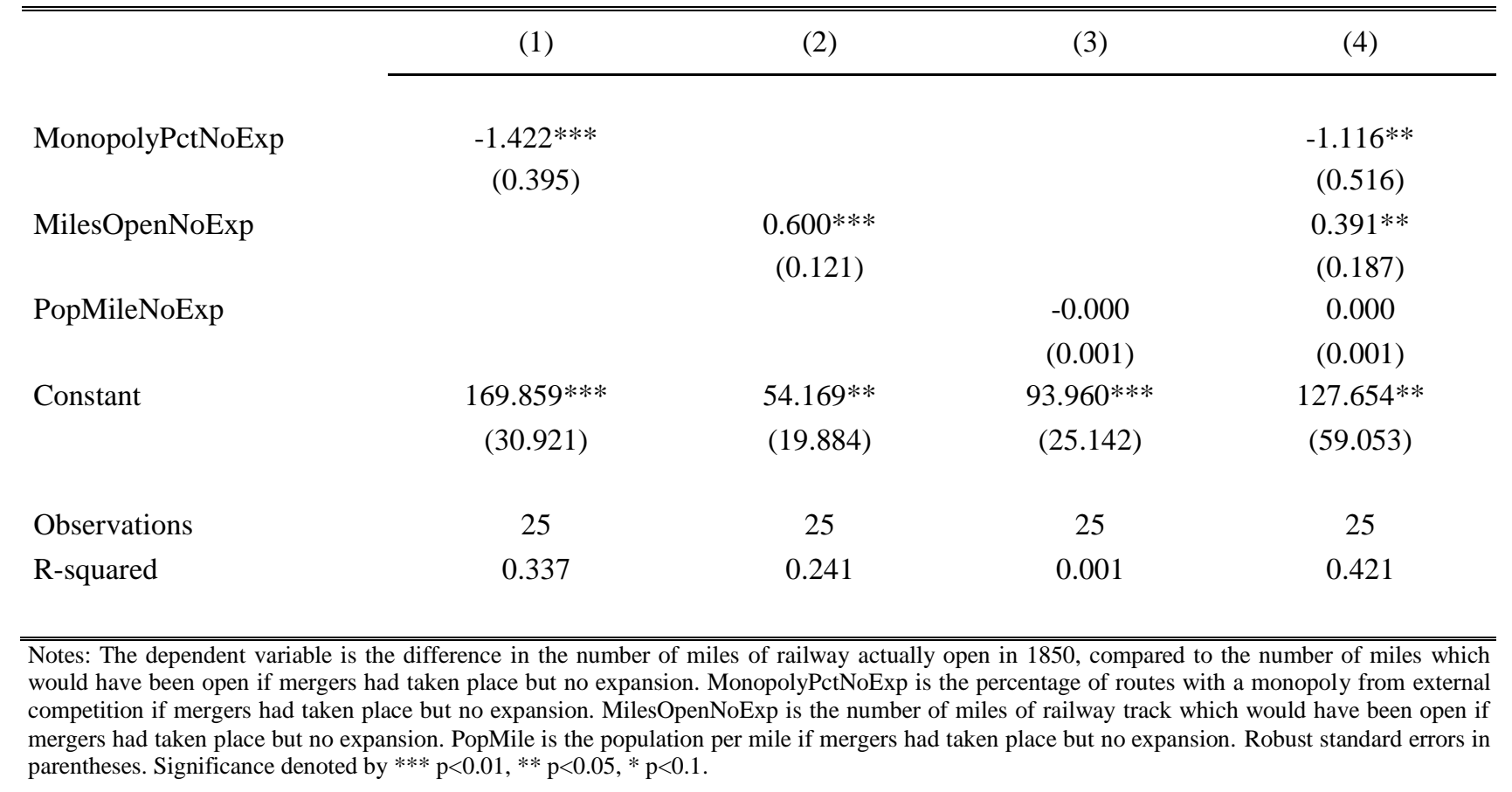


TABLE 9: RELATIONSHIP BETWEEN THE SIZE OF EACH COMPANY'S NETWORK AND FINANCIAL PERFORMANCE

\begin{tabular}{|c|c|c|c|c|}
\hline & $\begin{array}{c}(1) \\
\text { Profits } \\
/ \\
\text { Capital }\end{array}$ & $\begin{array}{c}(2) \\
\text { Receipts } \\
\text { (Total) } \\
/ \\
\text { Capital } \\
\end{array}$ & $\begin{array}{c}(3) \\
\text { Receipts } \\
\text { (Goods) } \\
/ \\
\text { Capital }\end{array}$ & $\begin{array}{c}(4) \\
\text { Receipts (Passengers) } \\
/ \\
\text { Capital }\end{array}$ \\
\hline MilesOpen & $\begin{array}{c}0.323 * * \\
(0.120)\end{array}$ & $\begin{array}{c}0.162 * * * \\
(0.056)\end{array}$ & $\begin{array}{l}0.146^{*} \\
(0.079)\end{array}$ & $\begin{array}{c}0.236 * * * \\
(0.057)\end{array}$ \\
\hline Constant & $\begin{array}{c}-5.291 * * * \\
(0.654)\end{array}$ & $\begin{array}{c}-3.658 * * * \\
(0.256)\end{array}$ & $\begin{array}{c}-4.341 * * * \\
(0.358)\end{array}$ & $\begin{array}{c}-4.763 * * * \\
(0.264)\end{array}$ \\
\hline $\begin{array}{l}\text { Observations } \\
\text { R-squared }\end{array}$ & $\begin{array}{c}17 \\
0.201\end{array}$ & $\begin{array}{c}55 \\
0.120\end{array}$ & $\begin{array}{c}55 \\
0.052\end{array}$ & $\begin{array}{c}55 \\
0.236\end{array}$ \\
\hline
\end{tabular}

Notes: All variables expressed in logs. MilesOpen is the number of miles of railway open for each company in 1850. Profits/Capital is the profitability of each company in 1850, scaled by the amount of capital invested in that company at the end of 1850 . Data calculated from Slaughter, M. (1850), 'Railway Intelligence, published under the authority of the Stock Exchange'. Receipts are the revenues in 1850 in total, and from goods and passengers respectively, Intelligence, published under the authority of the Stock Exchange'. Receipts are the revenues in 1850 in total, and from goods and passengers respectively,
scaled by the amount of capital invested in that company at the end of 1850. Data calculated from Parliamentary Papers (1851), LI, p.229, 'Railways. Return, scaled by the amount of capital invested in that company at the end of 1850. Data calculated from Parliamentary Papers (1851), LI, p.229, 'Railways. Return,
showing the Number of Passengers Conveyed on All the Railways in England and Wales, Scotland, and Ireland, respectively, during the half-year ending the showing the Number of Passengers Conveyed on All the Railways in England and Wales, Scotland, and Ireland, respectively, during the half-year ending the
30th June 1850', Parliamentary Papers (1851), LI, p.241, 'Railways. Return, showing the number of passengers conveyed on all the railways in England and 30th June 1850 ', Parliamentary Papers (1851), LI, p.241, 'Railways. Return, showing the number of passengers conveyed on all the railways in England and
Wales, Scotland, and Ireland, respectively, during the half-year ended the 31st December 1850' and Parliamentary Papers (1851), LI, p.177, Railways. Return, showing for each railway company the amount of capital and loans which the company has been authorized to raise by acts passed previous to and in 1850 ; the amount of share capital actually paid up on the 31 st day of December 1850 .' Robust standard errors in parentheses. Significance given by *** $\mathrm{p}<0.01, * * \mathrm{p}<0.05, * \mathrm{p}<0.1$. 
TABLE 10: RELATIONSHIP BETWEEN THE SIZE OF EACH COMPANY'S NETWORK AND COMPONENTS OF PASSENGER RECEIPTS

\begin{tabular}{|c|c|c|c|c|c|c|}
\hline & $\begin{array}{c}\text { (1) } \\
\text { Receipts } \\
\text { (Passengers) } \\
/ \\
\text { Capital } \\
\\
(\mathrm{r} / \mathrm{c}) \\
\end{array}$ & $\begin{array}{c}(2) \\
\text { Receipts } \\
\text { (Passengers) } \\
/ \\
\text { Passenger } \\
\text { Miles } \\
(\mathrm{r} / \mathrm{z})\end{array}$ & $\begin{array}{c}(3) \\
\text { Passenger } \\
\text { Miles } \\
/ \\
\text { Number of } \\
\text { Passengers } \\
(\mathrm{z} / \mathrm{p}) \\
\end{array}$ & $\begin{array}{c}(4) \\
\text { Number of } \\
\text { Passengers } \\
\text { / } \\
\text { Population of } \\
\text { Districts } \\
(\mathrm{p} / \mathrm{d}) \\
\end{array}$ & $\begin{array}{c}(5) \\
\text { Population of } \\
\text { Districts } \\
/ \\
\text { Miles } \\
\text { Open } \\
(\mathrm{d} / \mathrm{m}) \\
\end{array}$ & $\begin{array}{c}(6) \\
\text { Miles } \\
\text { Open } \\
/ \\
\text { Capital } \\
\\
(\mathrm{m} / \mathrm{c}) \\
\end{array}$ \\
\hline $\begin{array}{l}\text { MilesOpen } \\
\text { Constant }\end{array}$ & $\begin{array}{c}0.236 * * * \\
(0.057) \\
-4.763 * * * \\
(0.264)\end{array}$ & $\begin{array}{c}0.043 * * \\
(0.020) \\
-5.346^{* * *} \\
(0.091)\end{array}$ & $\begin{array}{c}0.331 * * * \\
(0.035) \\
1.184 * * * \\
(0.128)\end{array}$ & $\begin{array}{c}0.298 * * * \\
(0.077) \\
-0.681 * \\
(0.353)\end{array}$ & $\begin{array}{c}-0.272 * * * \\
(0.076) \\
9.666 * * * \\
(0.329)\end{array}$ & $\begin{array}{c}-0.164 * * * \\
(0.060) \\
-9.586 * * * \\
(0.271)\end{array}$ \\
\hline $\begin{array}{l}\text { Observations } \\
\text { R-squared }\end{array}$ & $\begin{array}{c}55 \\
0.236\end{array}$ & $\begin{array}{c}55 \\
0.084\end{array}$ & $\begin{array}{c}55 \\
0.590\end{array}$ & $\begin{array}{c}55 \\
0.234\end{array}$ & $\begin{array}{c}55 \\
0.236\end{array}$ & $\begin{array}{c}55 \\
0.134\end{array}$ \\
\hline \multicolumn{7}{|c|}{ 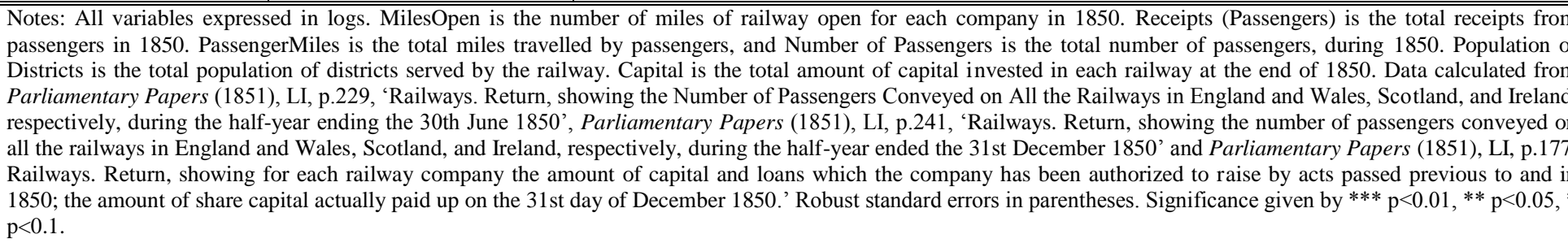 } \\
\hline
\end{tabular}


